Prepared in cooperation with the Maine Department of Transportation

\title{
Comparison of Peak-Flow Estimation Methods for Small Drainage Basins in Maine
}

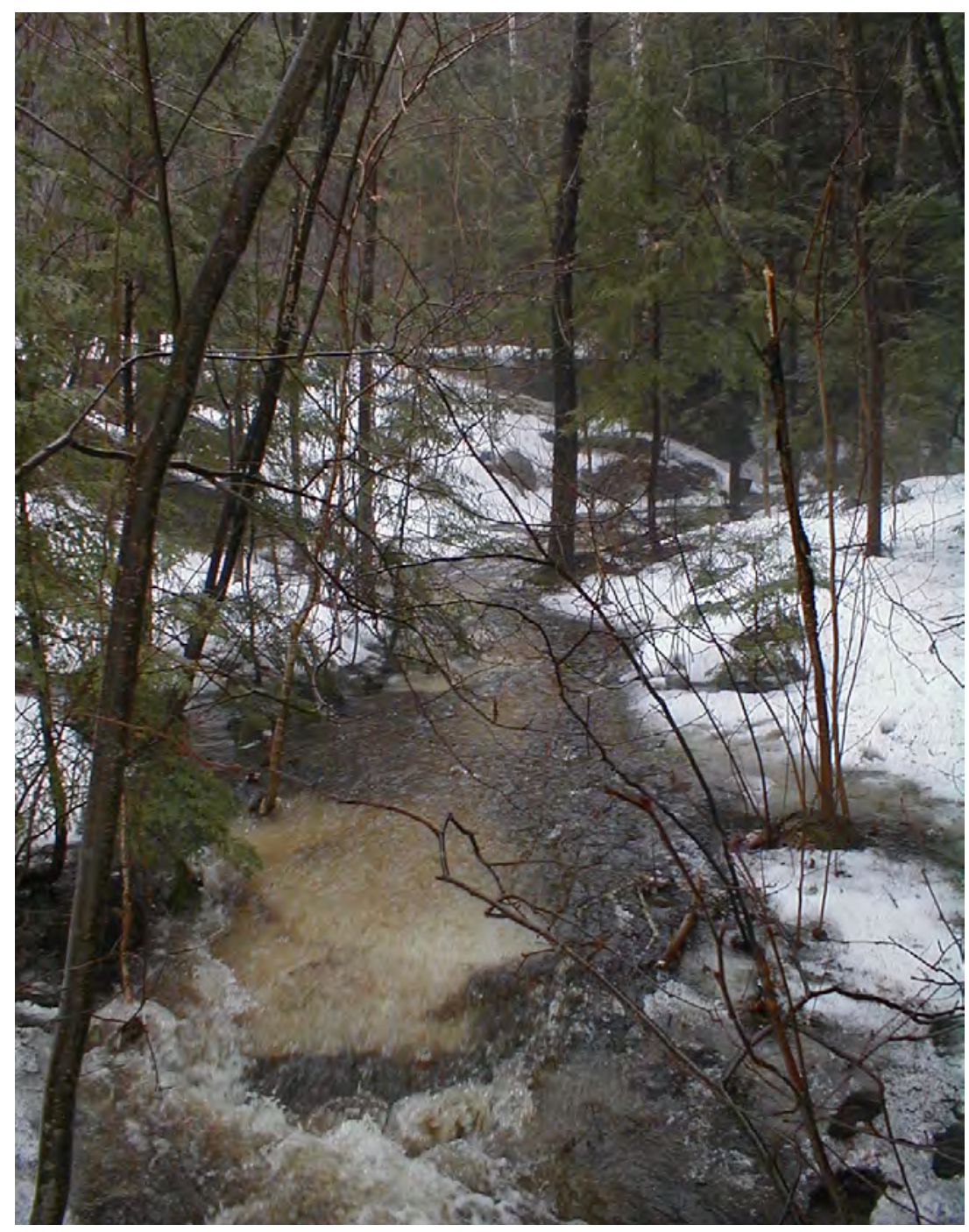

Scientific Investigations Report 2007-5170 
COVER: High streamflow in an unnamed brook near Gilead, Maine, March 28, 2000; taken by James Caldwell (USGS). 


\section{Comparison of Peak-Flow Estimation Methods for Small Drainage Basins in Maine}

By Glenn A. Hodgkins, Charles Hebson, Pamela J. Lombard, and Alexander Mann

Prepared in cooperation with the Maine Department of Transportation

Scientific Investigations Report 2007-5170 


\title{
U.S. Department of the Interior DIRK KEMPTHORNE, Secretary
}

\author{
U.S. Geological Survey \\ Mark D. Myers, Director
}

\section{U.S. Geological Survey, Reston, Virginia: 2007}

\begin{abstract}
For more information on the USGS--the Federal source for science about the Earth, its natural and living resources, natural hazards, and the environment:

World Wide Web: http://www.usgs.gov

Telephone: 1-888-ASK-USGS

Any use of trade, product, or firm names is for descriptive purposes only and does not imply endorsement by the U.S. Government.

Although this report is in the public domain, permission must be secured from the individual copyright owners to reproduce any copyrighted materials contained within this report.

Suggested citation:

Hodgkins, G.A., Hebson, Charles, Lombard, P.J., and Mann, Alexander, 2007, Comparison of peak-flow estimation methods for small drainage basins in Maine: U.S. Geological Survey Scientific Investigations Report 2007-5170, 32 p.
\end{abstract}




\section{Contents}

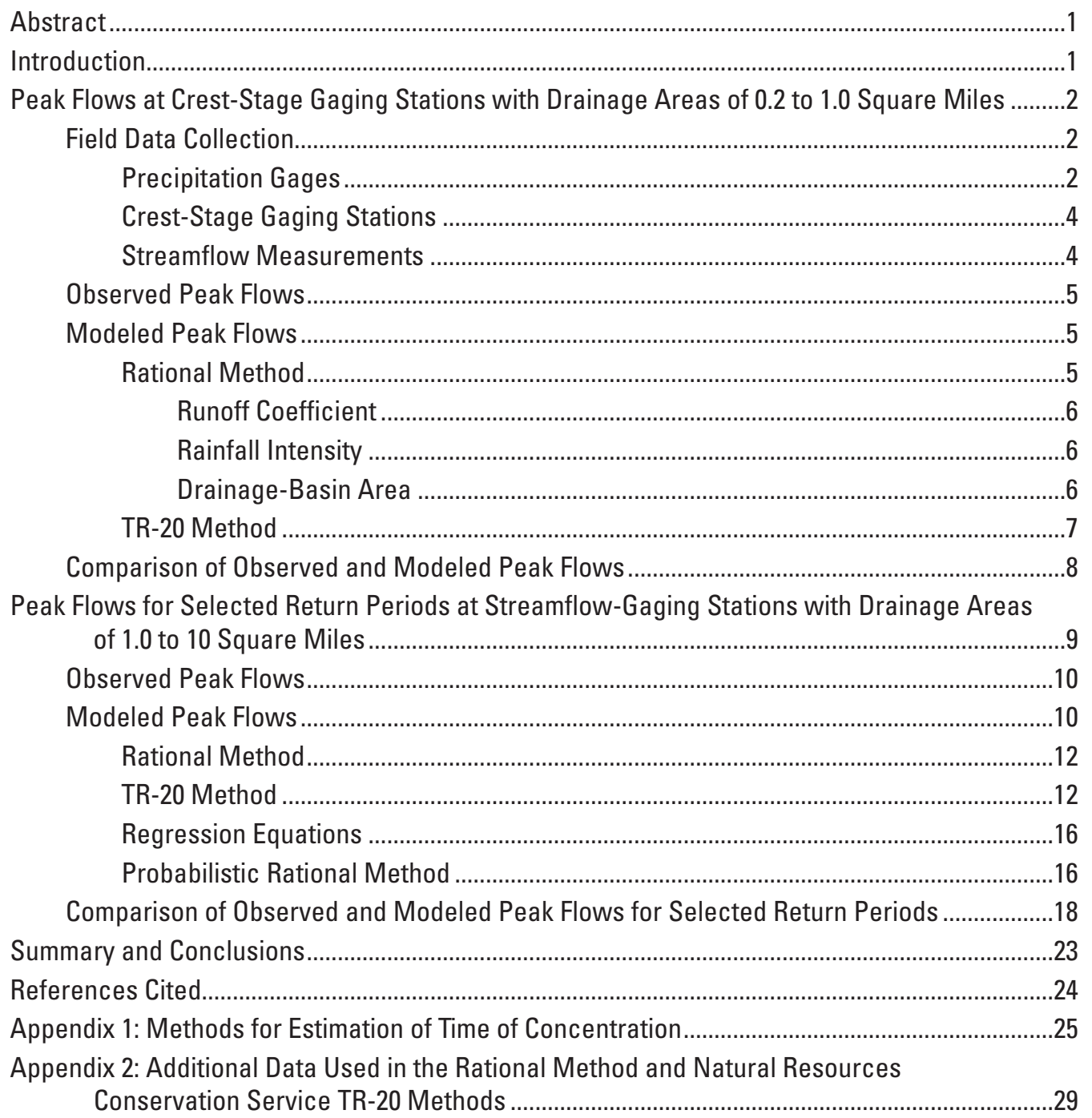




\section{Figures}

1-2. Maps showing:

1. Location of crest-stage gaging stations used in this study with drainage areas from 0.2 to 1.0 square miles.

2. Location of streamflow-gaging stations used in this study with drainage areas

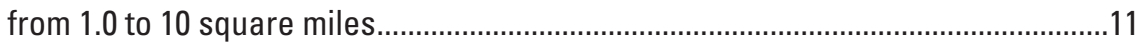

3-6. Graphs showing:

3. Modeled 50-year peak flows from the Rational Method plotted against observed 50-year peak flows.

4. Modeled 50-year peak flows from the Natural Resources Conservation Service TR-20 method plotted against observed 50-year peak flows.

5. Modeled 50-year peak flows from U.S. Geological Survey regression equations plotted against observed 50-year peak flows.

6. Modeled 50-year peak flows from the Probabilistic Rational Method plotted against observed 50 -year peak flows 


\section{Tables}

1. Crest-stage gaging stations established for very small drainage basins in Maine in 1999 and 2000 .

2. Summary of input parameters and modeled peak flows for the Rational Method for basins in Maine with drainage areas of 0.2 to 1.0 square miles

3. Summary of input parameters and modeled peak flows for the Natural Resources Conservation Service TR-20 method for basins in Maine with drainage areas of 0.2 to 1.0 square miles

4. Observed and modeled peak flows for basins in Maine with drainage areas of 0.2 to 1.0 square miles.

5. Observed peak flows for basins in Maine and New Hampshire with drainage areas of 1.0 to 10 square miles

6. Summary of input parameters for the Rational Method for basins with drainage areas of 1.0 to 10 square miles

7. Modeled peak flows using the Rational Method for basins in Maine and New Hampshire with drainage areas of 1.0 to 10 square miles.

8. Summary of input parameters for the Natural Resources Conservation Service TR-20 method for basins in Maine and New Hampshire with drainage areas of 1.0 to 10 square miles.

9. Modeled peak flows using the Natural Resources Conservation Service TR-20 method for basins in Maine and New Hampshire with drainage areas of 1.0 to 10 square miles

10. Modeled peak flows using U.S. Geological Survey regression equations for basins in Maine and New Hampshire with drainage areas of 1.0 to 10 square miles

11. Probabilistic Rational Method rainfall-runoff coefficients (C) for 2-, 10-, 25-, 50-, and 100-year return periods for 17 U.S. Geological Survey streamflow-gaging stations in Maine

12. Modeled peak flows using the Probabilistic Rational Method for basins in Maine and New Hampshire with drainage areas of 1.0 to 10 square miles.

13. Root mean square errors from comparison of modeled and observed peak 2-, 50-, and 100-year streamflows for basins in Maine and New Hampshire with drainage areas of 1.0 to 10 square miles 


\section{Conversion Factors, Datums and Abbreviations}

\begin{tabular}{|c|c|c|}
\hline Multiply & By & To obtain \\
\hline \multicolumn{3}{|c|}{ Length } \\
\hline inch (in.) & 2.54 & centimeter $(\mathrm{cm})$ \\
\hline inch (in.) & 25.4 & millimeter (mm) \\
\hline foot $(\mathrm{ft})$ & 0.3048 & meter $(\mathrm{m})$ \\
\hline mile (mi) & 1.609 & kilometer (km) \\
\hline \multicolumn{3}{|c|}{ Area } \\
\hline acre & 0.4047 & hectare (ha) \\
\hline square foot $\left(\mathrm{ft}^{2}\right)$ & 0.09290 & square meter $\left(\mathrm{m}^{2}\right)$ \\
\hline square mile $\left(\mathrm{mi}^{2}\right)$ & 2.590 & square kilometer $\left(\mathrm{km}^{2}\right)$ \\
\hline \multicolumn{3}{|c|}{ Volume } \\
\hline cubic foot $\left(\mathrm{ft}^{3}\right)$ & 0.02832 & cubic meter $\left(\mathrm{m}^{3}\right)$ \\
\hline \multicolumn{3}{|c|}{ Flow rate } \\
\hline foot per second $(\mathrm{ft} / \mathrm{s})$ & 0.3048 & meter per second $(\mathrm{m} / \mathrm{s})$ \\
\hline cubic foot per second $\left(\mathrm{ft}^{3} / \mathrm{s}\right)$ & 0.02832 & cubic meter per second $\left(\mathrm{m}^{3} / \mathrm{s}\right)$ \\
\hline inch per year (in/yr) & 25.4 & millimeter per year (mm/yr) \\
\hline
\end{tabular}

Temperature in degrees Fahrenheit $\left({ }^{\circ} \mathrm{F}\right)$ may be converted to degrees Celsius $\left({ }^{\circ} \mathrm{C}\right)$ as follows:

$$
{ }^{\circ} \mathrm{C}=\left({ }^{\circ} \mathrm{F}-32\right) / 1.8
$$

Vertical coordinate information is referenced to the North American Vertical Datum of 1988 (NAVD 88).

Horizontal coordinate information is referenced to the North American Datum of 1983 (NAD 83). Altitude, as used in this report, refers to distance above the vertical datum. 


\title{
Comparison of Peak-Flow Estimation Methods for Small Drainage Basins in Maine
}

\author{
By Glenn A. Hodgkins', Charles Hebson², Pamela J. Lombard', and Alexander Mann²
}

\section{Abstract}

Understanding the accuracy of commonly used methods for estimating peak streamflows is important because the designs of bridges, culverts, and other river structures are based on these flows. Different methods for estimating peak streamflows were analyzed for small drainage basins in Maine. For the smallest basins, with drainage areas of 0.2 to 1.0 square mile, nine peak streamflows from actual rainfall events at four crest-stage gaging stations were modeled by the Rational Method and the Natural Resource Conservation Service TR-20 method and compared to observed peak flows. The Rational Method had a root mean square error (RMSE) of -69.7 to 230 percent (which means that approximately two thirds of the modeled flows were within -69.7 to 230 percent of the observed flows). The TR-20 method had an RMSE of -98.0 to 5,010 percent. Both the Rational Method and TR-20 underestimated the observed flows in most cases.

For small basins, with drainage areas of 1.0 to 10 square miles, modeled peak flows were compared to observed statistical peak flows with return periods of 2, 50, and 100 years for 17 streams in Maine and adjoining parts of New Hampshire. Peak flows were modeled by the Rational Method, the Natural Resources Conservation Service TR-20 method, U.S. Geological Survey regression equations, and the Probabilistic Rational Method.

The regression equations were the most accurate method of computing peak flows in Maine for streams with drainage areas of 1.0 to 10 square miles with an RMSE of -34.3 to 52.2 percent for 50-year peak flows. The Probabilistic Rational Method was the next most accurate method (-38.5 to 62.6 percent). The Rational Method (-56.1 to 128 percent) and particularly the TR-20 method (-76.4 to 323 percent) had much larger errors. Both the TR-20 and regression methods had similar numbers of underpredictions and overpredictions. The Rational Method overpredicted most peak flows and the Probabilistic Rational Method tended to overpredict peak flows from the smaller (less than 5 square miles) drainage

\footnotetext{
${ }^{1}$ U.S. Geological Survey.

${ }^{2}$ Maine Department of Transportation.
}

basins and underpredict peak flows from larger drainage basins. The results of this study are consistent with the most comprehensive analysis of observed and modeled peak streamflows in the United States, which analyzed statistical peak flows from 70 drainage basins in the Midwest and the Northwest.

\section{Introduction}

Estimates of peak flows on small ungaged streams are frequently used for the design of culverts, bridges, and other river structures in Maine. The Maine Department of Transportation (MaineDOT) and others who design hydraulic structures in and near streams in Maine are interested in how well flood-estimation methods perform for peak flows of a given return period (such as the 50-year peak flow) on small basins (less than 10 square miles). The accurate design of structures on small basins is of great economic importance in Maine because small basins are so numerous.

Peak flows of a given return period can be estimated for small ungaged basins with statistical models, such as regression equations (for example: Hodgkins, 1999), or by simple rainfall-runoff models such as the Rational Method and the Natural Resources Conservation Service (NRCS) TR-20 method (Pilgrim and Cordery, 1993). To evaluate methods for determining peak flows, the U.S. Geological Survey (USGS) and MaineDOT began a study, starting with data collection, in 1999. The purpose of this report is to compare peak flows estimated from models to peak flows observed on gaged streams with small drainage basins in Maine to evaluate the accuracy of these estimation methods.

This report is divided into two sections based on the size of the drainage basin. For very small basins (drainage areas less than 1 square miles), an analysis of the accuracy of models for estimating flows of selected return periods is problematic because long-term streamflow data (at least 10 years) were available for only three streams of this size in Maine. Peak-streamflow data and rainfall data were collected specifically for this study for these very small basins. 
These data allow for the comparison of observed peak flows against modeled peak flows for the range of flows recorded during the study period. Data collection is ongoing (2007) for very small watersheds and long-term data should be available for these basins in the future. For basins with drainage areas of 1.0 to $10 \mathrm{mi}^{2}$, there is a sufficient number of continuousrecord streamflow-gaging stations in Maine with more than 10 years of record from which a comparison of observed flows and modeled flows can be conducted for peak flows with up to 100-year return periods.

Maine (fig. 1) is a mostly forested, rural state; the relief is predominately moderate to low throughout the state except for the Appalachian Mountains in west-central Maine (Randall, 2001). Streams in northern Maine generally drain remote, undeveloped forests. Streams in southern Maine generally drain rural areas with forests, small towns, some pasture land, and some low-density residential development. All of the streams in this study are in rural areas.

Maine has a temperate climate with mild summers and cold winters. From 1971 to 2000 , the mean annual temperature was about $42^{\circ} \mathrm{F}$, with a range from $36^{\circ} \mathrm{F}$ in northern Maine to $47^{\circ} \mathrm{F}$ in southern Maine. For the same time period, statewide mean monthly temperatures ranged from $15^{\circ} \mathrm{F}$ in January to $67^{\circ} \mathrm{F}$ in July. Precipitation in Maine is fairly evenly distributed throughout the year with a mean annual precipitation (1971 to 2000) of 43 in., ranging from 35 in. in northern Maine to 57 in. in eastern coastal Maine (National Oceanic and Atmospheric Administration, 2002).

The largest streamflows in New England typically are in the spring, when rain falls on a ripe (dense, ready to melt) snowpack or on saturated soils. Flows recede as snowmelt ends and as evapotranspiration increases. This flow recession is frequently interrupted by runoff from rainstorms. The lowest warm-season flows of the year are usually in August and September. In the fall, after evapotranspiration decreases substantially, repeated rains often saturate the soil, leading to large flows. Also in the fall, large flows can result from heavy rain from hurricanes, tropical storms, or their remnants. Winter flows are generally low in northern Maine, where most winter precipitation falls as snow. Winter flows in southern areas are more variable.

\section{Peak Flows at Crest-Stage Gaging Stations with Drainage Areas of 0.2 to 1.0 Square Miles}

Observed streamflows were compared to modeled streamflows for basins with drainage areas of 0.2 to $1.0 \mathrm{mi}^{2}$ using data collected specifically for this study. The accuracy of the Rational Method and the NRCS TR-20 method were evaluated on the basis of their ability to estimate actual streamflows recorded at four USGS crest-stage gaging stations from 1999 to 2002. Each observed peak flow was compared to the flow modeled from the corresponding rainfall event.

\section{Field Data Collection}

Precipitation, stream stage (height), and streamflow data were collected for this study at very small watersheds. Precipitation data were collected with recording rain gages. Stream-stage data were collected by use of crest-stage gaging stations. Streamflow measurements were made to calibrate the relation between stage and streamflow at the crest-stage gaging stations.

\section{Precipitation Gages}

A Novalynx model 260-2500 tipping-bucket recording rain gage with an 8-in. diameter orifice connected to a HOBO event logger was installed in 1999 and 2000 within a quarter mile of each of 15 crest-stage gaging stations in Maine (table 1). Rain gages were installed according to gage installation guidelines from the National Weather Service (1989) and were placed on a platform 4 to $5 \mathrm{ft}$ above the ground in clearings where the height of the surrounding protection (trees in most cases) did not exceed twice the distance from the gage. Rain gages were leveled initially and at each site visit. Windshields were not used on any of the rain gages. Only precipitation falling in the form of rain was used in the analyses. The gages were operated from approximately March to November of each year. Data were collected, downloaded, and examined at each site visit (every 8 to 12 weeks) during these months. 


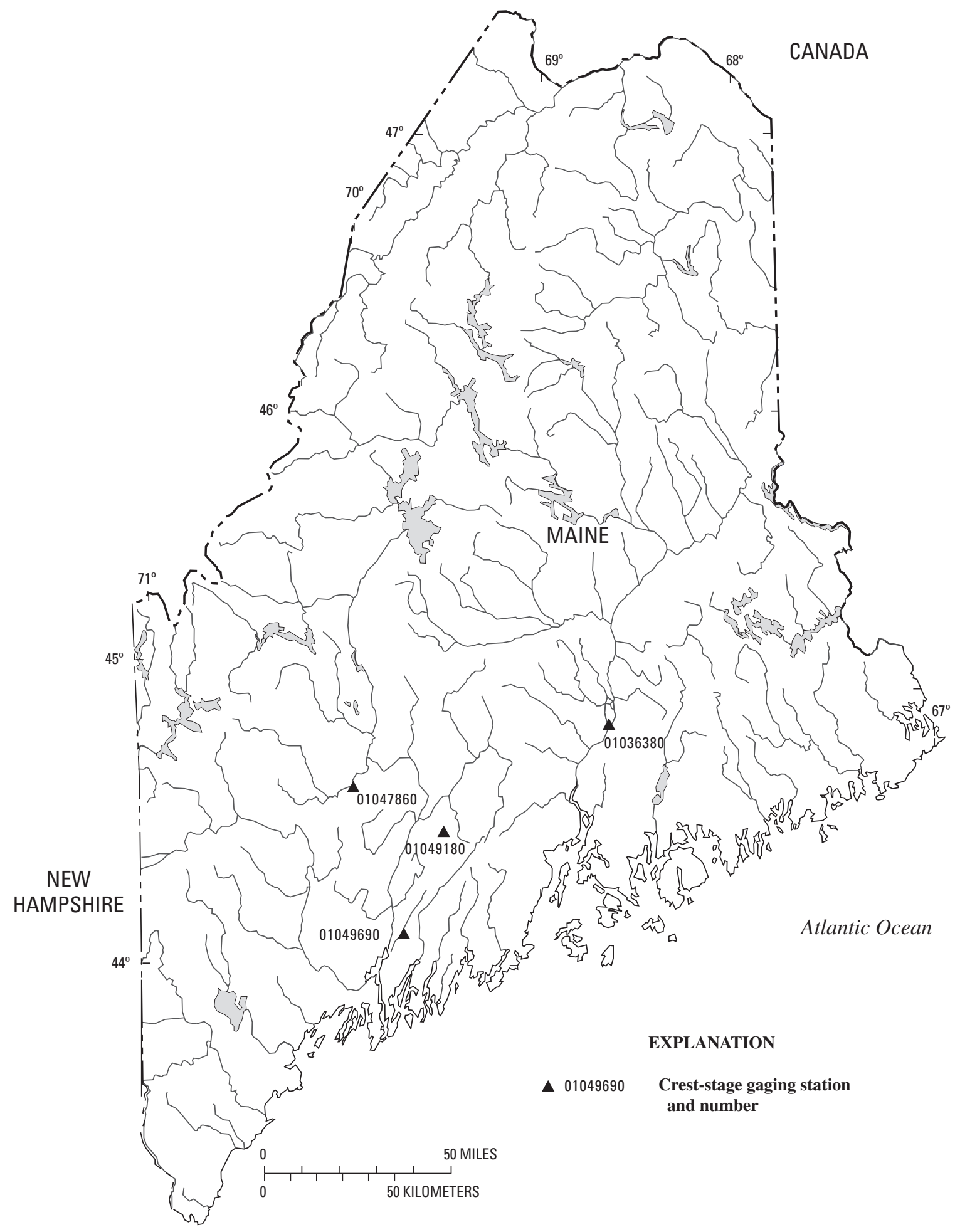

Base from U.S. Geological Survey digital data, 1990, 1:2,000,000 Universal Transverse Mercator projection Zone 19

Figure 1. Location of crest-stage gaging stations used in this study with drainage areas from 0.2 to 1.0 square miles. 
Table 1. Crest-stage gaging stations established for very small drainage basins in Maine in 1999 and 2000.

$\left[\mathrm{mi}^{2}\right.$, square miles]

\begin{tabular}{|c|c|c|}
\hline $\begin{array}{l}\text { Crest-stage } \\
\text { gaging } \\
\text { station } \\
\text { number }\end{array}$ & Crest-stage gaging station name & $\begin{array}{c}\text { Drainage } \\
\text { area } \\
\left(\mathrm{mi}^{2}\right)\end{array}$ \\
\hline 01012895 & Clark Brook near Wallagrass Plantation & 0.99 \\
\hline 01012970 & Unnamed brook near Wallagrass Plantation & .40 \\
\hline 01017045 & Unnamed brook near Presque Isle & .30 \\
\hline 01021075 & Unnamed brook near Baileyville & .27 \\
\hline 01021890 & Unnamed brook near Crawford & .66 \\
\hline 01031470 & Brewster Brook near Parkman & .70 \\
\hline $01036380^{1}$ & Unnamed brook near Bradley & .86 \\
\hline 01036385 & Unnamed brook near Eddington & .28 \\
\hline $01047860^{1}$ & Unnamed brook near New Sharon & .59 \\
\hline 01048840 & Unnamed brook near Newport & .22 \\
\hline $01049180^{1}$ & Unnamed brook near Albion & .45 \\
\hline $01049690^{1}$ & Unnamed brook near Dresden & .35 \\
\hline 01050490 & Unnamed brook near Rangeley & .51 \\
\hline 01054135 & Unnamed brook near Gilead & .36 \\
\hline 01065450 & Unnamed brook near Cornish & .54 \\
\hline
\end{tabular}

${ }^{1}$ Crest-stage gaging station with flow calibration by 2006 .

The rain gages were calibrated with a Novalynx Model 260-2595 precipitation-gage calibrator with $150 \mathrm{~mL}$ of water and nozzle sizes of $0.018 \mathrm{in}$. and $0.031 \mathrm{in}$. With an 8 -in. diameter rain gage, these nozzle sizes produce the equivalent of $0.33 \mathrm{in} / \mathrm{hr}$ and $2.0 \mathrm{in} / \mathrm{hr}$ of rain, respectively. Four calibration trials were made for each gage, two with the 0.031 -in. nozzle and two with the 0.018 -in. nozzle. If any one of those trials resulted in measurement errors of more than 6 percent, three additional trials were made. If any one of the three subsequent trials resulted in more than 6-percent measurement errors, the gage calibration screws were adjusted and the process was repeated.

The calibrations of the rain gages were checked in the field after significant rainfall events; $501 \mathrm{~mL}$ of water and a nozzle size of $0.0625 \mathrm{in}$. (the equivalent of $6 \mathrm{in} / \mathrm{hr}$ ) were used for one trial at each site. Four of the 15 sites with rain gages and crest-stage gaging stations were used in the final analyses for reasons described in the "Observed Peak Flows" section. For three of these four sites (New Sharon, Albion, Dresden; table 1) precipitation-measurement errors were less than
6 percent. The fourth site (Bradley) underregistered the water in the calibration trial by 9 percent.

\section{Crest-Stage Gaging Stations}

A crest-stage gaging station provides a means to economically collect data on very small drainage basins by recording the highest stage (stream height) that occurs at a stream between visits to the station. A stage-flow relation (rating curve) is developed to compute the flows associated with the recorded peak stages.

Fifteen crest-stage gaging stations were established across Maine in 1999 and 2000. Their locations were chosen on the basis of the following criteria: a contributing drainage area of $0.2 \mathrm{mi}^{2}$ to $1.0 \mathrm{mi}^{2}$, a diversity of drainage-basin characteristics (such as drainage-basin wetland area and slope) among sites, a single culvert in good condition at the measuring point, an adequate streamflow-measurement location, a nearby open area for a rain gage, and a low likelihood of road overflow at the culvert. Names, site numbers, and drainage areas of the 15 stations are given in table 1.

Crest-stage gaging stations were installed one culvert width upstream from the culvert entrance at all 15 sites according to the methods described in Rantz and others (1982). Downstream crest-stage gaging stations were installed one culvert width downstream from the culvert exit at the seven sites where backwater was possible. Stations were visited, read, and reset once every 8 to 12 weeks throughout each year, as well as before and after significant high-flow events.

\section{Streamflow Measurements}

All unmeasured streamflows at the crest-stage gaging stations were computed by means of a calibrated culvert hydraulic model (discussed in the next section). The model was used to develop the rating curve for the station. At least one streamflow measurement that can be linked to a stage (height) reading on the crest-stage gage was needed to calibrate each hydraulic model.

Flows on very small streams can reach a peak and recede very quickly (in a matter of hours), thus necessitating a method of measuring streams during periods of rapidly changing flow. All flow measurements were made using procedures appropriate for rapidly changing stage (Rantz and others, 1982, p.174-176). This modification of standard procedure reduced the time consumed in making a streamflow measurement by making a single velocity measurement at each vertical location, reducing the velocity measurement time by half and reducing the number of sections taken. A minimum of one and up to six flow measurements were made during each site visit at high flows. 


\section{Observed Peak Flows}

For this section of the report, observed peak flows at each crest-stage gaging station were determined from a stage-flow rating curve for each recorded peak stage. Rating curves were developed by use of the Culvert Analysis Program (Fulford, 1995). These streamflow values determined from the rating curve were treated as the observed flows and were used to evaluate the accuracy of the models that estimate peak flows at streams with very small drainage areas $\left(0.2\right.$ to $\left.1.0 \mathrm{mi}^{2}\right)$. The largest rainfall event between visits to the station was assumed to cause the peak stage recorded at the station.

Variables entered into the Culvert Analysis Program include culvert geometry and energy-loss coefficients, the elevations of the upstream and downstream ends of the culvert referenced to a local datum, approach-section geometry of the channel, and roughness values for the channel and the culvert. Measured flows at each site and their associated stages were used to calibrate the rating in the Culvert Analysis Program. After the rating was established, a peak flow was determined for each peak stage that could be linked to a rainfall event. Four of the 15 stations (table 1) were calibrated at the time of this report (2007). These four stations (01036380, 01047860 , 01049180, 01049690; table 1; fig. 1) were used to evaluate two methods of estimating peak flows later in this report.

\section{Modeled Peak Flows}

Peak streamflows for basins with drainage areas of 0.2 to $1.0 \mathrm{mi}^{2}$ were modeled in this study by the Rational Method and by the NRCS TR-20 method. Descriptions of these models and their application to this study are described in the following sections. These models were not calibrated to any observed flows in this study.

\section{Rational Method}

The Rational Method has been used for more than 100 years for calculating peak streamflows and is still the single most widely used rainfall-runoff model for small drainage basins. It is difficult to assign a precise upper limit on drainage-basin size for reliable Rational Method application; however, references cite upper limits ranging from 200 acres (Dunne and Leopold, 1978, p. 298) to 0.5 or $1.0 \mathrm{mi}^{2}$ (Ponce, 1989). General consensus is that best results are obtained for smaller, largely impervious (or urban) areas or, failing such conditions, areas that are relatively homogeneous in land use and cover. The Rational method is essentially a simple deterministic rainfall-runoff model. Dooge (1973) and Ponce (1989) place the Rational Method in a unit-hydrograph systems-modeling framework; Pilgrim and Cordery (1993) and McCuen (1998) also give informative modern presentations of this method.

The Rational Method for peak flow uses the equation

$$
Q=\alpha C I A,
$$

where

$$
\begin{aligned}
& Q \quad \text { is the peak streamflow, in cubic feet per } \\
& \text { second or cubic meters per second; } \\
& \alpha \quad \text { is a unit-conversion constant (1 for U.S. } \\
& \quad \text { Customary or 2.78 for metric); } \\
& C \quad \text { is the runoff coefficient (dimensionless); } \\
& I \quad \text { is uniform rainfall intensity, in inches per } \\
& \text { hour or millimeters per hour; and } \\
& \text { is drainage-basin area, in acres or hectares. }
\end{aligned}
$$

\begin{tabular}{|c|c|c|c|c|c|c|c|c|}
\hline $\begin{array}{l}\text { Crest-stage gaging } \\
\text { station name }\end{array}$ & $\begin{array}{l}\text { Crest-stage } \\
\text { gaging sta- } \\
\text { tion number }\end{array}$ & C & $\begin{array}{l}\text { Storm } \\
\text { date }\end{array}$ & $\begin{array}{c}\text { Rainfall } \\
\text { depth } \\
\text { (in.) } \\
\end{array}$ & $\begin{array}{c}\text { Rainfall } \\
\text { duration } \\
(\mathbf{h r})\end{array}$ & $\begin{array}{c}I \\
(\mathrm{in} / \mathrm{hr})\end{array}$ & $\begin{array}{c}A \\
\text { (acre) }\end{array}$ & $\begin{array}{c}\text { Modeled } \\
\text { peak flow } \\
\left(\mathrm{ft}^{3} / \mathrm{s}\right) \\
\end{array}$ \\
\hline Unnamed brook near Albion & 01049180 & 0.14 & $3 / 28 / 00$ & 1.67 & 5.60 & 0.30 & 289.0 & 12.1 \\
\hline \multirow[t]{3}{*}{ Unnamed brook near Bradley } & 01036380 & .22 & $3 / 28 / 00$ & 1.64 & 5.75 & .29 & 548.3 & 34.4 \\
\hline & & & $4 / 22 / 00$ & 1.26 & 10.65 & .12 & & 14.3 \\
\hline & & & $4 / 14 / 02$ & 1.63 & 9.60 & .17 & & 20.5 \\
\hline \multirow[t]{2}{*}{ Unnamed brook near Dresden } & 01049690 & .18 & $3 / 28 / 00$ & 2.01 & 5.65 & .36 & 226.4 & 14.5 \\
\hline & & & $6 / 02 / 01$ & 2.17 & 9.10 & .24 & & 9.7 \\
\hline \multirow[t]{3}{*}{ Unnamed brook near New Sharon } & 01047860 & .23 & $3 / 28 / 00$ & 3.75 & 5.55 & .68 & 376.4 & 58.5 \\
\hline & & & $4 / 22 / 00$ & 4.25 & 33.50 & .13 & & 11.0 \\
\hline & & & $5 / 19 / 01$ & .85 & 7.10 & .12 & & 10.4 \\
\hline
\end{tabular}

The input parameters and modeled peak flows for nine peak flows, from rainfall events at four crest-stage gaging stations, are listed in table 2.

Table 2. Summary of input parameters and modeled peak flows for the Rational Method for basins in Maine with drainage areas of 0.2 to 1.0 square miles.

$\left[C\right.$, runoff coefficient; $I$, rainfall intensity; $A$, area; in., inches; hr, hour; min, minutes; $\mathrm{ft}^{3} / \mathrm{s}$, cubic feet per second] 


\section{Runoff Coefficient}

The runoff coefficient $(C)$ is open to several interpretations. The original and also most intuitive and physically based meaning is that $C$ is simply the ratio of peak flow to average (volumetric) rainfall rate for actual storms. With this understanding, and when the Rational Method is used as a rainfall-runoff model to simulate actual peaks, $C$ is a deterministic drainage-basin parameter that lumps numerous physically meaningful drainage-basin parameters and the areal and temporal rainfall distribution. This physical interpretation of $C$ is used in this part of the report, where actual events are modeled; the alternative probabilistic interpretation is used later in this report, where the Rational Method is used to estimate flows of specified return periods (probability of occurrence).

The Rational Method relies on numerous simplifying assumptions that deviate from the actual functioning of drainage basins. Thus, $C$ has only a tenuous physical basis and is best understood as a fitting parameter. The assumptions of the Rational Method include the following: (1) rainfall is uniform over time and space, (2) time of concentration is independent of rainfall intensity, (3) $C$ does not vary with rainstorm intensity or antecedent soil moisture, (4) runoff is dominated by overland flow, and (5) basin storage effects are negligible (Hayes and Young, 2006).

To a certain extent, conditions in smaller, more uniform, and impervious drainage basins are closer to the underlying assumptions and therefore are better described by Rational Method hydrology than other drainage basins. In application, $C$ also might be allowed to vary with storm intensity, moisture conditions, and other factors that could be important; however, the effort to refine estimates of $C$ probably indicates the desirability of using other models.

McCuen (1998) and Pilgrim and Cordery (1993) provide values needed to make Rational-Method estimates and guidance in choosing parameter values for their use. The Rational-Method $C$-value was assigned in this study (table 2) according to land use and cover based on these commonly available tabulations. In the rural, undeveloped drainage basins considered here, $C$ generally ranges from 0.1 to 0.3 , although on poorly drained soil, $C$ can be as high as 0.5 . Assigned values for the four very small basins with drainage areas of 0.2 to $1.0 \mathrm{mi}^{2}$ ranged from 0.14 to 0.23 .

\section{Rainfall Intensity}

Rainfall intensity $(I)$ for the Rational Method is assumed to be uniform over the drainage basin and constant for the storm duration $\left(t_{d}\right)$. In this section of the report, where peak flows from actual rainfall events are modeled, the intensity is calculated as the ratio of actual rainfall depth to duration, assuming storm duration is greater than the drainage-basin time of concentration $\left(t_{c}\right)$. This time of concentration is characterized as the time for rain falling at the hydraulically most distant part of the drainage basin to reach the outlet. According to the linear-hydrograph theory underpinning the Rational Method, peak runoff results from a storm of given intensity persisting for a long enough time such that the entire drainage basin is contributing runoff at the outlet. For events of a specified intensity and duration $t_{d}<t_{c}$, the peak flows are less than the maximum peak flows obtained at $t_{d}=t_{c}$. For the same intensity, $t_{d}>t_{c}$ does not further increase the peak flow.

Two approaches are commonly used for estimating time of concentration-empirical equations such as the Kirpich and Kerby-Hathaway (K-H) equations, and conceptual-hydraulics methods. The conceptual-hydraulics methods used here (for example the TR-55 method) further depend on estimating travel-time components of the longest flow path from the basin divide to the outlet. These estimation methods are described in appendix 1.

For the Rational Method, in this section, drainage basin total time of concentration was computed by the TR-55 hydraulic method as the sum of the sheet-flow, shallowconcentrated-flow, and channel-flow traveltimes. Component time-of-concentration calculations are summarized in appendix 2, tables 2-1 through 2-3. The sheet-flow calculations include calculations by the TR-55 kinematicwave (KW) approximation and for comparison by the exact KW and the Kerby-Hathaway (K-H) methods. TR-55 and $\mathrm{K}-\mathrm{H}$ sheet-flow estimates are similar and tend to be somewhat larger than the 50- and 100-year KW estimates. The TR-55 estimates, being an approximation to the KW equation, would closely approximate the KW estimates if return-periodspecific storm depths were used, instead of the 2-year 24-hour depth. For the rainfall events used in this section, time of concentration was computed using the TR-55 method sheetflow approximation based on the 2-year storm depth and the velocity-factor formulation for shallow concentrated flow (see appendix 1 for details). The storm durations all exceeded the times of concentration, thus satisfying a major assumption of the Rational Method. A sheet-flow length of $100 \mathrm{ft}$ was used uniformly for all drainage basins likewise, shallow concentrated flow length was standardized at $150 \mathrm{ft}$. Sheet flow and shallow-concentrated-flow roughness (Manning's n) were generally 0.24 or 0.40 . Stream-channel length was based on blue-line channels denoted on USGS topographic maps. Slopes were estimated from USGS topographic maps. Standard references (for example, McCuen, 1998) were used to set roughness values.

\section{Drainage-Basin Area}

Drainage-basin area $(A)$ in the Rational Method is a straightforward parameter and requires little interpretation. The small drainage basins suitable for analysis with the Rational Method typically extend beyond the MaineDOT bridge/culvert project boundaries and thus may not be completely covered by the project plans and topographic information. They also can be too small for reliable delineation from standard USGS 7.5-minute topographic maps; therefore, drainage-basin delineations are commonly augmented by aerial-photograph interpretation. Field checking of delineations is particularly critical for small or relatively flat 
drainage basins. Also, ditches and culverts can significantly alter delineation and flow paths, as compared to simple delineation based on topography alone. For the four crest-stage gaging stations listed in table 2, drainage areas were delineated using topographic maps, aerial photographs, and field checks.

\section{TR-20 Method}

The NRCS Technical Release 20 (TR-20) model (Natural Resources Conservation Service, 1985-2000) is a widely used rainfall-runoff model for hydrologic-engineering design. It is a spatially distributed model that uses complete linear-hydrograph generation and routing through channels and storage elements. Thus it is a more powerful model than the Rational Method and is suitable for a wide variety of applications. HydroCad (HydroCAD Software Solutions LLC, 2004) is a proprietary implementation of TR-20 hydrology that has built-in methods and tables for common hydraulic structures, such as culverts and weirs. The HydroCad model was used to make the TR-20 calculations in this study. The two models use identical runoff-generation algorithms, as both use NRCS curve-number hydrology. HydroCad uses a channel-routing algorithm slightly different than the modified ATT-KIN algorithm in TR-20 for channel (routing) model elements. Because the drainage basins in this study are relatively small, the effect of different routing strategies on the final results is likely to be insignificant.

TR-20 is thoroughly described in other references (for example, Natural Resources Conservation Service, 1985-2000; McCuen, 1998; Ponce, 1989). Many of the same parameters used for the Rational Method are used for TR-20. Major differences between the Rational Method and TR-20 are presented here.

TR-20 is a distributed model, in the sense that the drainage basin can be divided into an arbitrary number of lumped subdrainage basins connected by channel reaches and storage elements. The Rational Method, on the other hand, is completely lumped and does not distinguish between runoff generation and routing components, nor does it explicitly account for drainage-basin storage.

Along with being spatially distributed, TR-20 generates and routes complete hydrographs, whereas the Rational Method calculates just the magnitude of a peak flow. Also, TR-20 rainfall input is specified as a temporally distributed rainfall hyetograph, as opposed to a uniform and constant rainfall intensity. Furthermore, subdrainage basins within the drainage basin can have separate input parameters.

Because of its inherent flexibility and seemingly limitless capacity for system complexity, TR-20 is widely used for analyzing pre- and post-development hydrology in projects where storage schemes are used to control runoff events of specified return periods. Such applications are commonly found in urban or urbanizing situations, even though TR-20 was originally developed for agricultural and rural applications. In design situations in small drainage basins where the special storage and routing capabilities of TR-20 are not needed, however, it is questionable whether TR-20 is any more accurate or reliable than the simpler Rational Method. In fact, the reliability of both methods for estimating design peak flows (peak flows of a specified return period) is not fully understood, although available research indicates that regression equations are more reliable and easier to use for estimating peak flows than simple noncalibrated rainfallrunoff models such as the Rational Method and TR-20 (Newton and Herrin, 1982).

It is generally accepted that TR-20 is a poor choice of model for simulating actual rainfall-runoff events (Pilgrim and Cordery, 1993) although it is widely used for estimating runoff from hypothetical design events (for example, a 50-year rainfall). It is not entirely clear that this is a meaningful distinction, especially because TR-20 performance for estimating return-period flows from design storms is yet to be established. The general understanding seems to be that TR-20 is useful in determining relative changes in peak flows related to increased development. In transportation engineering, however, the objective is to design structures for flood magnitudes of specified return periods. The ability to simulate real events may provide some indication of a method's ability to accurately predict design peak flows.

The TR-20 input variables for this study were developed in parallel with the Rational Method, as both methods require the same or similar information. In particular, times of concentration were determined in virtually the same way for the two models. Also, with a single description of land use and cover, the appropriate values of $C$ or curve number for runoff generation can be determined. Although the Rational Method is a lumped model, land use in the initial characterization stage can be characterized as a distributed property for later lumping by areal averaging. Thus, in a study such as this, the Rational and TR-20 methods require much the same level of effort.

The only significant additional information required for the TR-20 method is characterization of drainage-basin storage. The Rational Method does not explicitly account for storage effects, whereas TR-20 allows for the distribution of storage throughout a drainage basin with storage being modeled as a linear reservoir. Storage was assigned in the larger drainage basins where topography indicated likely storage effects, such as in wetlands or large, nearly closed drainage areas. Storage elements were parameterized by a water-surface area-elevation function. Storage outlets were generally modeled as broadcrested weirs or culverts. In detailed project-specific modeling studies, storage can be further refined by field inspection of channel reaches and flood plains; in natural drainage basins with limited resources for data collection, however, treatment of storage is largely approximate.

In addition to storage elements, TR-20 also can include hydraulic structures such as highway culverts, but culvertperformance curves and structure-rating curves must be developed outside the model using other methods. The HydroCad implementation of TR-20 processes hydraulic structures within the program. This HydroCad capability was useful, because the very small crest-stage gaging-station 
Table 3. Summary of input parameters and modeled peak flows for the Natural Resources Conservation Service TR-20 method for basins in Maine with drainage areas of 0.2 to 1.0 square miles.

[Sheet-flow length is $100 \mathrm{ft}$ for all stations; shallow-concentrated-flow length is $150 \mathrm{ft}$ for all stations; channel-flow area is $5.0 \mathrm{ft}^{2}$ for all stations; $\mathrm{CN}$, curve number; $\mathrm{ft}^{3} / \mathrm{s}$, cubic feet per second]

\begin{tabular}{lcccc}
\hline \multicolumn{1}{c}{ Crest-stage gaging station name } & $\begin{array}{c}\text { Crest-stage gaging } \\
\text { station number }\end{array}$ & Storm date & CN & $\begin{array}{c}\text { Modeled peak flow } \\
\left(\mathbf{f t}^{3} / \mathbf{s}\right)\end{array}$ \\
\hline Unnamed brook near Albion & 01049180 & $3 / 28 / 00$ & 43 & 0.0 \\
Unnamed brook near Bradley & 01036380 & $3 / 28 / 00$ & 73 & 1.2 \\
& & $4 / 22 / 00$ & & .1 \\
Unnamed brook near Dresden & 01049690 & $4 / 14 / 02$ & & 1.1 \\
& & $3 / 28 / 00$ & 58 & 3.9 \\
Unnamed brook near New Sharon & \multirow{2}{*}{01047860} & $6 / 02 / 01$ & & 3.9 \\
& & $3 / 28 / 00$ & 79 & 212.9 \\
& & $4 / 22 / 00$ & & 41.0 \\
\hline
\end{tabular}

basins in this study were chosen on the basis of culverts available for flow estimation at their outlet.

The simplest modeled basins consisted of a single drainage basin element with no channel or storage elements. These models are highly analogous to the corresponding lumped Rational Method models. The times of concentrations of the runoff-generating basins were calculated identically to the Rational Method times of concentrations. Most of the models included a single storage element, because this allowed for direction specification of the basin-outlet culvert. To the extent that these culverts passed under deep fill beneath a roadway, this also allowed for simulation of storage in the flood plain upstream from the road. As a practical matter, most of these storage elements had little effect on attenuating the calculated peak flows.

A summary of TR-20 input parameters and modeled peak flows for the basins with drainage areas of 0.2 to $1.0 \mathrm{mi}^{2}$ is given in table 3 and in appendix 2 in tables 2-1 and 2-3. Runoff-curve numbers were assigned according to land use and cover, as well as soil type and associated hydrologic soil groups (McCuen, 1998; Natural Resources Conservation Service, 1986). Of the four crest-stage gaging stations in this section, only the Bradley Basin showed a significant storage effect.

\section{Comparison of Observed and Modeled Peak Flows}

Observed and modeled peak flows for nine peak flows from actual rainfall events at four crest-stage gaging stations are given in table 4. With the exception of two of the New Sharon rainfall events, the rainfall depths corresponding to the measured flows are well under the 2-year, 24-hour storm depth. The two largest New Sharon storms are somewhat larger and smaller than the 10-year, 24-hour depth representative of the area.

The logarithms (base 10) of the observed and modeled peak flows were calculated, and logarithms of the observed peak flows were subtracted from the logarithms of the modeled flows. These differences are the basis for the rest of the comparison discussed here. By computing the difference of the logarithms of the peak flows, the ratio of the modeled flows to the observed flows is calculated, rather than the arithmetic difference. If not analyzed in this manner, the difference between the modeled and observed flows for smaller drainage basins would have looked smaller than the difference calculated for larger drainage basins. For example, if the observed peak flow is $1,000 \mathrm{ft}^{3} / \mathrm{s}$ and a modeled peak flow is $1,100 \mathrm{ft}^{3} / \mathrm{s}$, the absolute difference between the two would be $100 \mathrm{ft}^{3} / \mathrm{s}$. For an observed flow of $100 \mathrm{ft}^{3} / \mathrm{s}$ and a modeled flow of $200 \mathrm{ft}^{3} / \mathrm{s}$, the absolute difference also would be $100 \mathrm{ft}^{3} / \mathrm{s}$. However, $200 \mathrm{ft}^{3} / \mathrm{s}$ is twice as large as $100 \mathrm{ft}^{3} / \mathrm{s}$, whereas $1,100 \mathrm{ft}^{3} / \mathrm{s}$ is only 1.1 times as large as $1,000 \mathrm{ft}^{3} / \mathrm{s}$. Also, by using the logarithms of the flows, a modeled flow that is half of the observed flow will show the same difference as one that is twice the observed flow. For example, with an observed flow of $100 \mathrm{ft}^{3} / \mathrm{s}$ and a modeled flow of $200 \mathrm{ft}^{3} / \mathrm{s}$, the logarithm of the modeled flow minus the logarithm of the observed flow is 0.3 . For an observed flow of $100 \mathrm{ft}^{3} / \mathrm{s}$ and modeled flow of $50 \mathrm{ft}^{3} / \mathrm{s}$, the difference of the logarithms is -0.3 .

The root-mean-square error (RMSE) was used as the overall measure of accuracy for the two methods of modeling peak flows for ungaged streams. A lower RMSE indicates a better overall accuracy. The RMSE is computed as the square root of (the sum of the squared differences between the logarithms of the observed and modeled flows, divided 
Table 4. Observed and modeled peak flows for basins in Maine with drainage areas of 0.2 to 1.0 square miles.

[in., inches; hr, hours; $\mathrm{ft}^{3} / \mathrm{s}$, cubic feet per second]

\begin{tabular}{|c|c|c|c|c|c|c|c|}
\hline Crest-stage gaging-station name & $\begin{array}{c}\text { Crest-stage } \\
\text { gaging- } \\
\text { station } \\
\text { number }\end{array}$ & Storm date & $\begin{array}{c}\text { Rainfall } \\
\text { depth } \\
\text { (in.) }\end{array}$ & $\begin{array}{c}\text { Rainfall } \\
\text { duration } \\
\text { (hr) }\end{array}$ & $\begin{array}{c}\text { Observed } \\
\text { peak flow } \\
\left(\mathrm{ft}^{3} / \mathrm{s}\right)\end{array}$ & $\begin{array}{c}\text { Rational } \\
\text { Method peak } \\
\text { flow } \\
\left(\mathrm{ft}^{3} / \mathbf{s}\right)\end{array}$ & $\begin{array}{l}\text { TR-20 peak } \\
\text { flow } \\
\left(\mathrm{ft}^{3} / \mathrm{s}\right)\end{array}$ \\
\hline Unnamed brook near Albion & 01049180 & $3 / 28 / 00$ & 1.67 & 5.60 & 25.7 & 12.1 & 0.0 \\
\hline \multirow[t]{3}{*}{ Unnamed brook near Bradley } & 01036380 & $3 / 28 / 00$ & 1.64 & 5.75 & 52.7 & 34.4 & 1.2 \\
\hline & & $4 / 22 / 00$ & 1.26 & 10.65 & 25.9 & 14.3 & .1 \\
\hline & & $4 / 14 / 02$ & 1.63 & 9.60 & 19.4 & 20.5 & 1.1 \\
\hline \multirow[t]{2}{*}{ Unnamed brook near Dresden } & 01049690 & $3 / 28 / 00$ & 2.01 & 5.65 & 50.3 & 14.5 & 3.9 \\
\hline & & $6 / 02 / 01$ & 2.17 & 9.10 & 200 & 9.7 & 3.9 \\
\hline \multirow[t]{3}{*}{ Unnamed brook near New Sharon } & 01047860 & $3 / 28 / 00$ & 3.75 & 5.55 & 97.6 & 58.5 & 212.9 \\
\hline & & $4 / 22 / 00$ & 4.25 & 33.50 & 18.2 & 11.0 & 41.0 \\
\hline & & $5 / 19 / 01$ & .85 & 7.10 & 21.3 & 10.4 & 8.4 \\
\hline
\end{tabular}

by the number of crest-stage gaging stations). The RMSE is converted to percentage errors using equations from Riggs (1968). Approximately 68 percent of the modeled flows for each method are within the given percentages of the observed flows.

The Rational Method had an RMSE of $0.519 \log$ units or -69.7 to 230 percent; TR-20 had an RMSE of $1.71 \mathrm{log}$ units or -98.0 to 5,010 percent. Both the Rational Method and TR-20 underestimated the observed flows in most cases, with the TR-20 method having much larger errors on average (table 4).

Interpretations of these results are limited by the relatively small sample size of nine peak flows at four sites. The errors in the Rational Method may result from the determination of the runoff coefficient $(C)$. It is unknown how well the $C$ values reflect the ratio of peak flow to average rainfall intensity (the assumed physical meaning of the values) for different regions with varying hydrologic regimes. The tabulated $C$ values used in the Rational Method largely reflect judgment rather than hard data (Pilgrim and Cordery, 1993).

The TR-20 method had much larger errors than the Rational Method at the sites evaluated in this study. The TR-20 method is generally thought to be more accurate than the Rational Method because of the explicit consideration of the various factors that are thought to affect flood runoff (Pilgrim and Cordery, 1993). This poor performance of the TR-20 method is consistent with extensive previous tests of this method when it was used as a deterministic model. The problems may be caused by the choice of curve number (Pilgrim and Cordery, 1993).

The sensitivity of modeled peak flows to curve number can be seen for the modeled basins in this study. For example, the modeled peak flows for the New Sharon Basin were very sensitive to the curve-number value assigned to 248 acres of the 303-acre basin. On the basis of soil-survey maps, these
248 acres were identified as type C and D soils and assigned a composite curve number of 79 . Reducing the curve number to 60 - a typical value for woodlands or meadow type B soils - cut the estimated peak flows by about 50 percent. For the Albion Basin, increasing the dominant curve number from 36 (A soil) to 70 (C soil) increased the modeled flow from $0.0 \mathrm{ft}^{3} / \mathrm{s}$ to $17 \mathrm{ft}^{3} / \mathrm{s}$. When ungaged basins are modeled, a range of parameter values can reasonably be inferred from maps, photographs, and field visits. The resulting peakflow estimates appear to be quite sensitive to the chosen parameters in this range, making substantial underestimation and overestimation of peak flows likely. Modeled peak flows also can be sensitive to basin storage. The modeled peak flows for the Bradley Basin were affected by a storage element that reduced the peak on 3/28/00 from $44.6 \mathrm{ft}^{3} / \mathrm{s}$ to $1.2 \mathrm{ft}^{3} / \mathrm{s}$.

\section{Peak Flows for Selected Return Periods at Streamflow-Gaging Stations with Drainage Areas of 1.0 to 10 Square Miles}

Peak flows from rainfall-runoff models and from statistical models were compared to statistical peak flows calculated from observed data for basins with drainage areas of 1.0 to $10 \mathrm{mi}^{2}$. Data from long-term continuousrecord streamflow-gaging stations at basins of this size in Maine are sufficient to allow for the evaluation of methods frequently used to calculate 2-year, 50-year, and 100-year peak flows. Methods evaluated include the Rational Method, the NRCS TR-20 method, USGS regression equations, and the Probabilistic Rational Method. 
Table 5. Observed peak flows for basins in Maine and New Hampshire with drainage areas of 1.0 to 10 square miles.

$\left[\mathrm{mi}^{2}\right.$, square miles; $\mathrm{ft}^{3} / \mathrm{s}$, cubic feet per second]

\begin{tabular}{|c|c|c|c|c|c|}
\hline $\begin{array}{c}\text { Streamflow- } \\
\text { gaging- } \\
\text { station } \\
\text { number }\end{array}$ & Streamflow-gaging-station name & $\begin{array}{c}\text { Drainage } \\
\text { area } \\
\left(\mathrm{mi}^{2}\right)\end{array}$ & $\begin{array}{c}\text { 2-year peak } \\
\text { flow } \\
\left(\mathrm{ft}^{3} / \mathbf{s}\right)\end{array}$ & $\begin{array}{c}\text { 50-year peak } \\
\text { flow } \\
\left(\mathrm{ft}^{3} / \mathrm{s}\right)\end{array}$ & $\begin{array}{c}100 \text {-year peak } \\
\text { flow } \\
\left(\mathrm{ft}^{3} / \mathrm{s}\right)\end{array}$ \\
\hline 01014700 & Factory Brook near Madawaska, Maine & 5.81 & 158.9 & 341.1 & 377.8 \\
\hline 01015700 & Houlton Brook near Oxbow, Maine & 6.45 & 122.2 & 268.0 & 297.7 \\
\hline 01017300 & Nichols Brook near Caribou, Maine & 4.06 & 105.2 & 335.1 & 391.9 \\
\hline 01017900 & Marley Brook near Ludlow, Maine & 1.33 & 84.7 & 305.4 & 363.7 \\
\hline 01021300 & Wiggins Brook near West Lubec, Maine & 5.21 & 268.0 & 762.7 & 882.8 \\
\hline 01026800 & Frost Pond near Sedgwick, Maine & 6.77 & 170.5 & 437.8 & 494.3 \\
\hline 01030300 & Trout Brook near Danforth, Maine & 4.46 & 145.8 & 497.9 & 586.1 \\
\hline 01034900 & Coffin Brook near Lee, Maine & 2.16 & 68.5 & 184.7 & 210.8 \\
\hline 01049100 & Hall Brook at Thorndike, Maine & 4.73 & 204.1 & $1,108.7$ & $1,408.9$ \\
\hline 01049130 & Johnson Brook at South Albion, Maine & 2.29 & 73.1 & 233.0 & 273.3 \\
\hline 01049300 & North Branch Tanning Brook near Manchester, Maine & 1.05 & 74.9 & 191.4 & 218.2 \\
\hline 01050900 & Four Ponds Brook near Houghton, Maine & 3.04 & 98.9 & 377.8 & 452.0 \\
\hline 01062700 & Patte Brook near Bethel, Maine & 5.33 & 224.2 & 946.3 & $1,147.6$ \\
\hline 01064200 & Mill Brook near Old Orchard, Maine & 2.40 & 90.7 & 264.1 & 303.7 \\
\hline 01066100 & Pease Brook near Cornish, Maine & 4.63 & 159.2 & 565.0 & 674.4 \\
\hline 01072850 & Mohawk Brook near Center Strafford, New Hampshire & 7.23 & 205.0 & $1,290.0$ & $1,720.0$ \\
\hline 01073600 & Dudley Brook near Exeter, New Hampshire & 5.56 & 143.0 & 520.0 & 639.0 \\
\hline
\end{tabular}

\section{Observed Peak Flows}

Peak flows in this part of the report refer to peak flows of specified return periods (also known as recurrence intervals). The return period is the average period of time between peak flows that are greater than a specified peak flow. For example, the 50-year peak flow is the flow that would be exceeded, on long-term average, once in 50 years. Peak-flows for 15 USGS streamflow-gaging stations in Maine with drainage areas of 1.0 to $10 \mathrm{mi}^{2}$ are from Hodgkins (1999) (table 5). Peak flows for the 2 stations in New Hampshire are from LeBlanc (1978). The flows from Hodgkins (1999) are the station estimates (all estimates are from a log-Pearson Type III probability distribution fitted to annual peak flows at stations with longterm continuous records), not the estimates that were weighted with estimates from the regression equations in the report. The peak flows for selected return periods are referred to as the "observed" values for this section of the report (table 5). The locations of these streamflow-gaging stations are shown in figure 2. These observed values were used to evaluate the accuracy of the regression and rainfall-runoff models for basins with drainage areas of 1.0 to $10 \mathrm{mi}^{2}$.

\section{Modeled Peak Flows}

Peak streamflows for basins with drainage areas of 1.0 to $10 \mathrm{mi}^{2}$ were modeled by the Rational Method, the NRCS TR-20 method, USGS regression equations, and the Probabilistic Rational Method. The rainfall-runoff models were not calibrated to any observed flows in this study. 


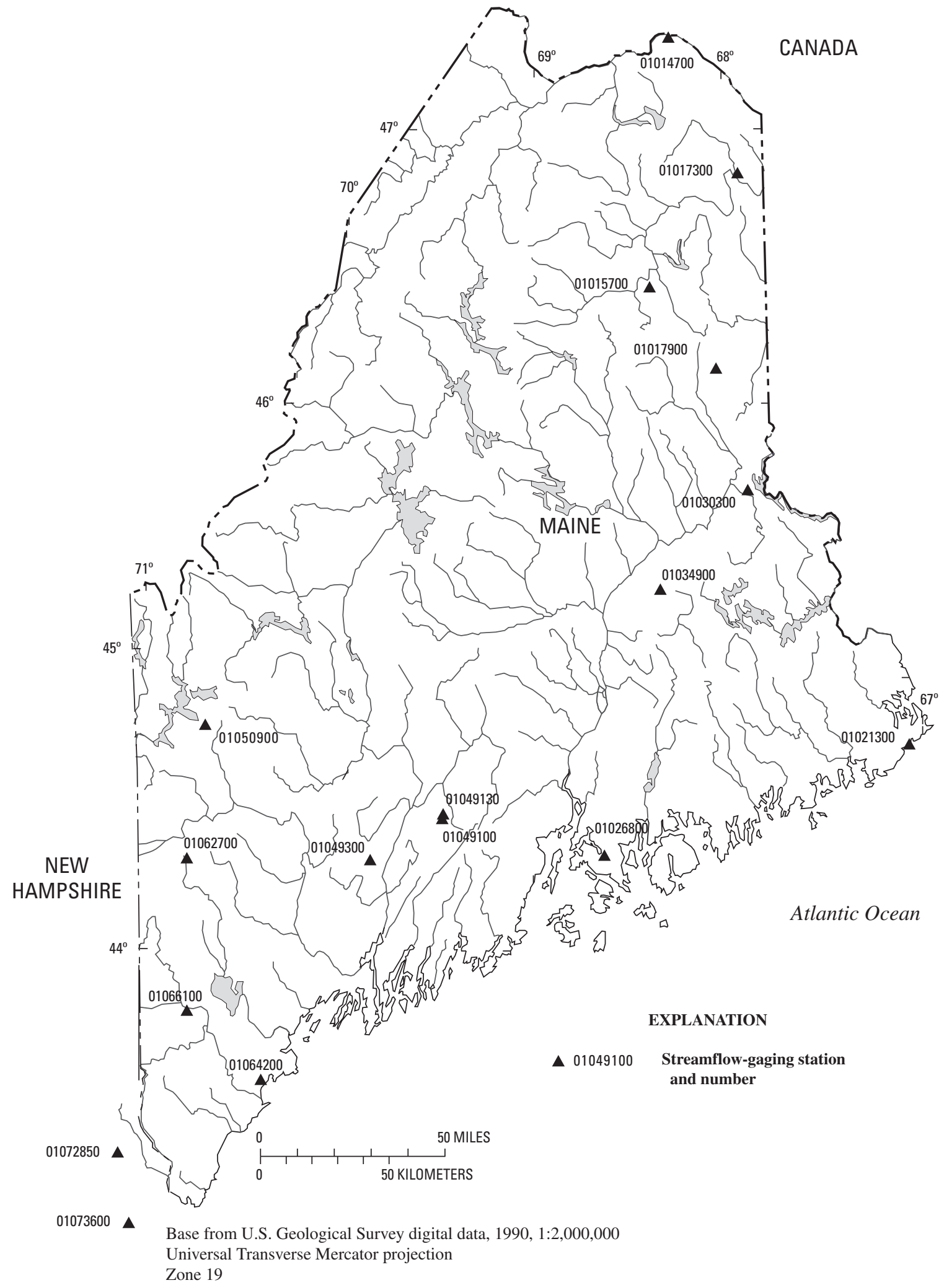

Figure 2. Location of streamflow-gaging stations used in this study with drainage areas from 1.0 to 10 square miles. 


\section{Rational Method}

The background and application of the Rational Method is described in detail in the preceding "Peak Flows at CrestStage Gaging Stations with Drainage Areas of 0.2 to 1.0 Square Miles" section of this report. This section focuses on differences in the application of the Rational Method for basins with drainage areas of 1.0 to $10 \mathrm{mi}^{2}$. In the previous section, the Rational Method was used to calculate peak flows from drainage basins using rainfall data from actual storms; in this section, the Rational Method is used to calculate peak flows of specified return periods.

Following traditional practice, it was assumed that the $T$-year storm produces the $T$-year runoff event, where $T$ is a return period of a specified number of years. For a given storm depth of return period $T$, an infinite combination of storm durations and intensities could produce that depth. The intensity-duration pair that maximizes the runoff is the chosen design event. This corresponds to a storm duration $\left(t_{d}\right)$ equal to the drainage-basin time of concentration $(t)$. Intensity-duration events for the drainage basins analyzed in this section were chosen with the aid of location-specific intensity-durationfrequency (IDF) curves. For a specified duration and return period, the IDF curve gives the design-average storm intensity.

Drainage-basin characteristics used for the Rational Method are summarized in table 6. The flow-component traveltimes are given in appendix 2, tables 2-1 to 2-3. Modeled peak flows from the Rational Method for 2-, 50- and 100-year return periods are given in table 7 .

\section{TR-20 Method}

The background and application of the TR-20 method is described in detail in the preceding "Peak Flows at Crest-Stage Gaging Stations with Drainage Areas of 0.2 to 1.0 Square Miles" section of this report. This section focuses on differences in the application of the TR-20 method between the small basins described in this section and the very small basins described in the previous section. In the previous section, the TR-20 method was used to calculate peak flows from drainage basins using rainfall data from actual storms;

Table 6. Summary of input parameters for the Rational Method for basins with drainage areas of 1.0 to 10 square miles.

[C, runoff coefficient; IDF, intensity-duration-frequency; in/hr, inches per hour; $I$, rainfall intensity; $A$, area; IDF sites: N, Newport, ME; R, Rangeley, ME; PI, Presque Isle, ME; P, Portland, ME; M, Millinocket, ME; E, Eastport, ME; ST, Strafford, NH; RO, Rockingham, NH; Maine IDF data from State of Maine (2005); New Hampshire IDF data from New Hampshire Department of Transportation (1998)]

\begin{tabular}{|c|c|c|c|c|c|c|c|}
\hline $\begin{array}{c}\text { Streamflow- } \\
\text { gaging-station } \\
\text { number }\end{array}$ & Streamflow-gaging-station name & C & $\begin{array}{l}\text { IDF } \\
\text { site }\end{array}$ & $\begin{array}{c}I \\
2-y r \\
\text { (in/hr) }\end{array}$ & $\begin{array}{c}I \\
50-y r \\
\text { (in/hr) }\end{array}$ & $\begin{array}{c}I \\
100-y r \\
\text { (in/hr) }\end{array}$ & $\begin{array}{c}A \\
\text { (acre) }\end{array}$ \\
\hline 01015700 & Houlton Brook near Oxbow, Maine & .17 & PI & .39 & .88 & .99 & $4,131.1$ \\
\hline 01017300 & Nichols Brook near Caribou, Maine & .24 & PI & .66 & 1.44 & 1.62 & $2,597.2$ \\
\hline 01021300 & Wiggins Brook near West Lubec, Maine & .18 & $\mathrm{E}$ & .70 & 1.64 & 1.84 & $3,335.3$ \\
\hline 01026800 & Frost Pond near Sedgwick, Maine & .23 & $\mathrm{~N}$ & 1.22 & 2.41 & 2.70 & $4,330.6$ \\
\hline 01030300 & Trout Brook near Danforth, Maine & .26 & $\mathrm{E}$ & .41 & .90 & 1.01 & $2,853.2$ \\
\hline 01034900 & Coffin Brook near Lee, Maine & .20 & M & .63 & 1.34 & 1.50 & $1,380.9$ \\
\hline 01049300 & North Branch Tanning Brook near Manchester, Maine & .18 & $\mathrm{~N}$ & 1.16 & 2.29 & 2.57 & 669.8 \\
\hline 01050900 & Four Ponds Brook near Houghton, Maine & .12 & $\mathrm{R}$ & 1.35 & 2.73 & 3.05 & $1,942.6$ \\
\hline 01062700 & Patte Brook near Bethel, Maine & .16 & $\mathrm{R}$ & 1.54 & 3.07 & 3.45 & $3,408.7$ \\
\hline 01064200 & Mill Brook near Old Orchard, Maine & .23 & $\mathrm{P}$ & 1.22 & 2.41 & 2.66 & $1,533.5$ \\
\hline 01066100 & Pease Brook near Cornish, Maine & .14 & $\mathrm{P}$ & 1.19 & 2.35 & 2.60 & $2,962.0$ \\
\hline 01072850 & Mohawk Brook near Center Strafford, New Hampshire & .19 & ST & .91 & 1.84 & 2.03 & $4,625.7$ \\
\hline 01073600 & Dudley Brook near Exeter, New Hampshire & .20 & RO & .71 & 1.46 & 1.62 & $3,561.5$ \\
\hline
\end{tabular}


Table 7. Modeled peak flows using the Rational Method for basins in Maine and New Hampshire with drainage areas of 1.0 to 10 square miles.

[ft $\mathrm{ft}^{3} / \mathrm{s}$, cubic feet per second]

\begin{tabular}{|c|c|c|c|c|}
\hline $\begin{array}{l}\text { Streamflow- } \\
\text { gaging-station } \\
\text { number }\end{array}$ & Streamflow-gaging-station name & $\begin{array}{c}\text { 2-year } \\
\text { peak flow } \\
\left(\mathrm{ft}^{3} / \mathrm{s}\right)\end{array}$ & $\begin{array}{c}\text { 50-year } \\
\text { peak flow } \\
\left(f^{3} / s\right)\end{array}$ & $\begin{array}{c}\text { 100-year } \\
\text { peak flow } \\
\left(\mathrm{ft}^{3} / \mathrm{s}\right)\end{array}$ \\
\hline 01014700 & Factory Brook near Madawaska, Maine & 828 & 1,704 & 1,921 \\
\hline 01015700 & Houlton Brook near Oxbow, Maine & 269 & 611 & 689 \\
\hline 01017300 & Nichols Brook near Caribou, Maine & 415 & 904 & 1020 \\
\hline 01017900 & Marley Brook near Ludlow, Maine & 245 & 490 & 551 \\
\hline 01021300 & Wiggins Brook near West Lubec, Maine & 466 & 1,001 & 1,123 \\
\hline 01026800 & Frost Pond near Sedgwick, Maine & 1,200 & 2,367 & 2,655 \\
\hline 01030300 & Trout Brook near Danforth, Maine & 312 & 676 & 759 \\
\hline 01034900 & Coffin Brook near Lee, Maine & 173 & 367 & 411 \\
\hline 01049100 & Hall Brook at Thorndike, Maine & 345 & 711 & 804 \\
\hline 01049130 & Johnson Brook at South Albion, Maine & 246 & 498 & 561 \\
\hline 01049300 & North Branch Tanning Brook near Manchester, Maine & 138 & 273 & 306 \\
\hline 01050900 & Four Ponds Brook near Houghton, Maine & 302 & 609 & 682 \\
\hline 01062700 & Patte Brook near Bethel, Maine & 822 & 1,643 & 1,848 \\
\hline 01064200 & Mill Brook near Old Orchard, Maine & 432 & 849 & 940 \\
\hline 01066100 & Pease Brook near Cornish, Maine & 483 & 953 & 1,055 \\
\hline 01072850 & Mohawk Brook near Center Strafford, New Hampshire & 789 & 1,598 & 1,769 \\
\hline 01073600 & Dudley Brook near Exeter, New Hampshire & 490 & 1,015 & 1,123 \\
\hline
\end{tabular}

in this section, the TR-20 method is used to calculate peak flows of specified return periods.

The TR-20 method was applied to the 17 drainage basins for which peak flows of specified return periods were available. Most of these drainage basins are considerably more complex than the very small drainage basins described earlier in the report; they contain multiple subdrainage basins, storage elements, and reaches. For the more complex drainage basins, the overall time of concentration is only approximate and is based on the combination of slowest subdrainage basin as well as longest combined reach length to the outlet. The effect of storage is not included in this overall estimate and has the effect of further increasing the apparent time of concentration.

Measured storm rainfall of a given intensity was used to compute TR-20 estimates for the basins with very small drainage areas. For basins with small drainage areas in this section, the $T$-year 24-hr storm depth is used to calculate the $T$-year runoff. In TR-20 design hydrology, storm depth acts as a scaling factor used to transform a dimensionless 24-hour rainfall distribution into a rainfall hyetograph of specified return period. Design storm depths are tabulated by county for the State of Maine (Maine Department of Environmental Protection, 1995) and for New Hampshire (New Hampshire Department of Environmental Services, written commun., 2006). TR-20 offers several different dimensionless hyetographs for so-called NRCS design storms distinguished by shape. These dimensionless distributions are not based on actual storms; rather, they are derived from depths for specified return periods and a range of durations (6 minutes to 24 hours). McCuen (1998) gives a clear explanation of how dimensionless distributions are constructed. In this study, all storms were specified as Type II with Antecedent Moisture Condition 2. Basic TR-20 model parameters used for the basins with small drainage areas in this section are summarized in table 8; additional details of model parameters are given in appendix 2.

Modeled peak flows for 2-, 50- and 100-year return periods are given in table 9 . These estimates were not calibrated to any measured flows. The runoff-curve numbers were assigned according to land use and cover. 
Table 8. Summary of input parameters for the Natural Resources Conservation Service TR-20 method for basins in Maine and New Hampshire with drainage areas of 1.0 to 10 square miles.

[ $\mathrm{CN}$, curve number; in., inches]

\begin{tabular}{llllllc}
\hline $\begin{array}{c}\text { Station } \\
\text { number }\end{array}$ & \multicolumn{1}{c}{ Streamflow-gaging-station name } & $\begin{array}{c}\text { Area } \\
\text { (acres) }\end{array}$ & CN & $\begin{array}{c}\text { 2-yr } \\
\text { rainfall } \\
\text { (in.) }\end{array}$ & $\begin{array}{c}\mathbf{5 0 - y r} \\
\text { rainfall } \\
\text { (in.) }\end{array}$ & $\begin{array}{c}\text { 100-yr } \\
\text { rainfall } \\
\text { (in.) }\end{array}$ \\
\hline 01014700 & Factory Brook near Madawaska, Maine & $3,716.9$ & 53 & 2.3 & 4.4 & 4.8 \\
01015700 & Houlton Brook near Oxbow, Maine & $4,131.1$ & 71 & 2.1 & 4.6 & 5.0 \\
01017300 & Nichols Brook near Caribou, Maine & $2,597.2$ & 70 & 2.3 & 4.4 & 4.8 \\
01017900 & Marley Brook near Ludlow, Maine & 850.4 & 60 & 2.1 & 4.6 & 5.0 \\
01021300 & Wiggins Brook near West Lubec, Maine & $3,335.3$ & 67 & 2.5 & 5.4 & 5.9 \\
01026800 & Frost Pond near Sedgwick, Maine & $4,330.6$ & 66 & 2.7 & 5.5 & 6.0 \\
01030300 & Trout Brook near Danforth, Maine & $2,853.2$ & 66 & 2.5 & 5.4 & 5.9 \\
01034900 & Coffin Brook near Lee, Maine & $1,380.9$ & 60 & 2.5 & 4.9 & 5.4 \\
01049100 & Hall Brook at Thorndike, Maine & $3,025.5$ & 65 & 2.8 & 5.5 & 6.0 \\
01049130 & Johnson Brook at South Albion, Maine & $1,462.5$ & 50 & 3.0 & 5.6 & 6.1 \\
01049300 & North Branch Tanning Brook near Manchester, Maine & 669.8 & 57 & 3.0 & 5.6 & 6.1 \\
01050900 & Four Ponds Brook near Houghton, Maine & $1,942.6$ & 48 & 3.5 & 6.6 & 7.1 \\
01062700 & Patte Brook near Bethel, Maine & $3,408.7$ & 75 & 3.5 & 6.6 & 7.1 \\
01064200 & Mill Brook near Old Orchard, Maine & $1,533.5$ & 66 & 3.2 & 6.0 & 6.6 \\
01066100 & Pease Brook near Cornish, Maine & $2,962.0$ & 45 & 3.0 & 6.4 & 6.9 \\
01072850 & Mohawk Brook near Center Strafford, New Hampshire & $4,625.7$ & 62 & 2.9 & 5.6 & 6.3 \\
01073600 & Dudley Brook near Exeter, New Hampshire & $3,561.5$ & 71 & 3.0 & 5.8 & 6.4 \\
\hline
\end{tabular}


Table 9. Modeled peak flows using the Natural Resources Conservation Service TR-20 method for basins in Maine and New Hampshire with drainage areas of 1.0 to 10 square miles.

$\left[\mathrm{ft}^{3} / \mathrm{s}\right.$, cubic feet per second]

\begin{tabular}{|c|c|c|c|c|}
\hline $\begin{array}{c}\text { Streamflow- } \\
\text { gaging- } \\
\text { station } \\
\text { number } \\
\end{array}$ & Streamflow-gaging-station name & $\begin{array}{c}\text { 2-year } \\
\text { peak flow } \\
\left(\mathrm{ft}^{3} / \mathrm{s}\right)\end{array}$ & $\begin{array}{c}\text { 50-year } \\
\text { peak flow } \\
\left(\mathrm{ft}^{3} / \mathrm{s}\right)\end{array}$ & $\begin{array}{c}\text { 100-year } \\
\text { peak flow } \\
\left(\mathrm{ft}^{3} / \mathrm{s}\right)\end{array}$ \\
\hline 01014700 & Factory Brook near Madawaska, Maine & 169 & 1,199 & 1,629 \\
\hline 01015700 & Houlton Brook near Oxbow, Maine & 79 & 235 & 259 \\
\hline 01017300 & Nichols Brook near Caribou, Maine & 121 & 535 & 645 \\
\hline 01017900 & Marley Brook near Ludlow, Maine & 9 & 339 & 435 \\
\hline 01021300 & Wiggins Brook near West Lubec, Maine & 122 & 1,239 & 1,267 \\
\hline 01026800 & Frost Pond near Sedgwick, Maine & 18 & 183 & 231 \\
\hline 01030300 & Trout Brook near Danforth, Maine & 17 & 71 & 82 \\
\hline 01034900 & Coffin Brook near Lee, Maine & 40 & 515 & 662 \\
\hline 01049100 & Hall Brook at Thorndike, Maine & 211 & 858 & 962 \\
\hline 01049130 & Johnson Brook at South Albion, Maine & .2 & 2.0 & 2.6 \\
\hline 01049300 & North Branch Tanning Brook near Manchester, Maine & 24 & 225 & 280 \\
\hline 01050900 & Four Ponds Brook near Houghton, Maine & 3.5 & 315 & 394 \\
\hline 01062700 & Patte Brook near Bethel, Maine & 378 & 1,165 & 1,300 \\
\hline 01064200 & Mill Brook near Old Orchard, Maine & 96 & 868 & 1,103 \\
\hline 01066100 & Pease Brook near Cornish, Maine & 6.6 & 444 & 647 \\
\hline 01072850 & Mohawk Brook near Center Strafford, New Hampshire & 78 & 641 & 873 \\
\hline 01073600 & Dudley Brook near Exeter, New Hampshire & 616 & 2,887 & 3,844 \\
\hline
\end{tabular}


The times of concentration were calculated according to the conceptual-hydraulics method with the TR-55 kinematicwave approximation for sheet flow (see appendix 1 for more details) using maps and aerial photographs. Times of concentration were evaluated for sheet-flow lengths of $25 \mathrm{ft}$, $100 \mathrm{ft}$, and $200 \mathrm{ft}$ during preliminary analyses. The average differences between the TR-20 peak-flow estimates and the observed peak flows (comparisons between modeled and observed flows for several methods are discussed in a later section) were not very sensitive to sheet-flow length; the RMSEs for TR-20 using sheet flow lengths of 25 and $200 \mathrm{ft}$ were less than 3 percent different from the RMSE using sheet flow lengths of $100 \mathrm{ft}$. Results are reported here only for a sheet-flow length of $100 \mathrm{ft}$.

\section{Regression Equations}

Hodgkins (1999) presented regression equations that model the peak flows for ungaged, unregulated streams in rural drainage basins for return periods of 2, 5, 10, 25, 50, 100, and 500 years. The equations were developed using generalized least-squares-regression procedures with 70 USGS streamflow-gaging stations in Maine and eastern New Hampshire; the equations use the explanatory (independent) variables of drainage area and basin wetlands. Peak flows with return periods of 2, 50, and 100 years were computed from these regression equations for the 17 stations with small drainage-basin areas (table 10).

\section{Probabilistic Rational Method}

The Rational Method is described fully in "Peak Flows at Crest-Stage Gaging Stations with Drainage Areas of 0.2 to 1.0 Square Miles" section of this report. In the application of the Rational Method, the estimated peak flow varies with the magnitude of the estimated runoff coefficient, $C$. Design $C$ values are commonly chosen on the basis of soil and landcover types in a drainage basin (Pilgrim and Cordery, 1993).

Table 10. Modeled peak flows using U.S. Geological Survey regression equations for basins in Maine and New Hampshire with drainage areas of 1.0 to 10 square miles.

$\left[\mathrm{ft}^{3} / \mathrm{s}\right.$, cubic feet per second]

\begin{tabular}{clccc}
\hline $\begin{array}{c}\text { Streamflow- } \\
\text { gaging-station } \\
\text { number }\end{array}$ & \multicolumn{1}{c}{ Streamflow-gaging-station name } & $\begin{array}{c}\text { 2-year } \\
\text { peak flow } \\
\left(\mathbf{f t}^{3} / \mathbf{s}\right)\end{array}$ & $\begin{array}{c}\mathbf{5 0 - y e a r} \\
\text { peak flow } \\
\left(\mathbf{f t}^{\mathbf{3}} \mathbf{s} \mathbf{s}\right)\end{array}$ & $\begin{array}{c}\text { 100-year } \\
\text { peak flow } \\
\left(\mathbf{f t}^{3} / \mathbf{s}\right)\end{array}$ \\
\hline 01014700 & Factory Brook near Madawaska, Maine & 321.4 & $1,112.7$ & $1,313.0$ \\
01015700 & Houlton Brook near Oxbow, Maine & 97.7 & 270.5 & 311.4 \\
01017300 & Nichols Brook near Caribou, Maine & 157.1 & 516.4 & 606.1 \\
01017900 & Marley Brook near Ludlow, Maine & 111.7 & 435.0 & 521.1 \\
01021300 & Wiggins Brook near West Lubec, Maine & 149.8 & 461.1 & 537.2 \\
01026800 & Frost Pond near Sedgwick, Maine & 126.6 & 380.3 & 441.8 \\
01030300 & Trout Brook near Danforth, Maine & 111.2 & 336.8 & 391.8 \\
01034900 & Coffin Brook near Lee, Maine & 63.8 & 203.1 & 237.8 \\
01049100 & Hall Brook at Thorndike, Maine & 268.3 & 924.6 & $1,090.6$ \\
01049130 & Johnson Brook at South Albion, Maine & 94.6 & 302.1 & 353.7 \\
01049300 & North Branch Tanning Brook near Manchester, Maine & 55.4 & 209.0 & 249.6 \\
01050900 & Four Ponds Brook near Houghton, Maine & 79.2 & 224.6 & 259.4 \\
01062700 & Patte Brook near Bethel, Maine & 258.5 & 864.4 & $1,016.2$ \\
01064200 & Mill Brook near Old Orchard, Maine & 129.0 & 472.4 & 561.7 \\
01066100 & Pease Brook near Cornish, Maine & 230.6 & 783.8 & 923.2 \\
01072850 & Mohawk Brook near Center Strafford, New Hampshire & 437.0 & $1,458.4$ & $1,712.9$ \\
01073600 & Dudley Brook near Exeter, New Hampshire & 153.2 & 474.8 & 553.5 \\
\hline
\end{tabular}


The Probabilistic Rational Method involves rearranging the Rational Method to

$$
C_{T}=Q_{T} /\left(I_{T} A\right)
$$

where

$C_{T} \quad$ is the dimensionless runoff coefficient for a given return period, $T$;

$Q_{T} \quad$ is the observed peak flow for that return period, in cubic feet per second;

$I_{T} \quad$ is the rainfall intensity in inches per hour estimated from a design rainfall intensityduration-frequency curve for that location and return period; and

$A$ is the area, in acres, of the drainage basin.

$C_{T}$ values are developed for as many basins and return periods as regional data permit. Calculated values of $C$ for a selected return period (50 years, for example) can be related to basin characteristics by regression or mapped over a region (Pilgrim and Cordery, 1993).

The Probabilistic Rational Method was first developed by Horner and Flynt (1936) and later used by French and others (1974) on rural basins to derive regional $C$ values for varying return periods. In the Probabilistic Rational Method, $C$ represents the ratio of peak runoff of a given frequency to rainfall of the same frequency and a duration equal to the time of concentration (Dooge, 1973, p. 83). This method has been used extensively in Australia to derive $C$ values for small- and medium-sized basins. In a study of 271 drainage basins in Australia, estimates of peak flow for the basins were made with the Probabilistic Rational Method and with the traditional Rational Method. Values from the traditional Rational Method compared very poorly to values from the Probabilistic Rational Method (Pilgrim, 1989; Pilgrim and others, 1989).

For this study, $C$ values for 2-, 10-, 25-, 50-, and 100-year return periods were developed for the 17 USGS streamflowgaging stations in Maine with drainage areas of $1.0 \mathrm{mi}^{2}$ to $10 \mathrm{mi}^{2}$ and a minimum of 10 years of peak-flow records (table 11). Drainage areas and 2-, 10-, 25-, 50-, and 100year peak flows were taken from Hodgkins (1999). The peak flows were the best estimate of peak flows at each station (station values weighted with regression-estimate values). Rainfall intensities for the 2-, 10-, 25-, 50-, and 100-year return periods were taken from MaineDOT IDF curves for the nearest of six locations in Maine (State of Maine, 2005).

Table 11. Probabilistic Rational Method rainfall-runoff coefficients (C) for 2-, 10-, 25-, 50-, and 100-year return periods for 17 U.S. Geological Survey streamflow-gaging stations in Maine.

\begin{tabular}{|c|c|c|c|c|c|c|}
\hline $\begin{array}{c}\text { Streamflow- } \\
\text { gaging-station } \\
\text { number }\end{array}$ & Streamflow-gaging-station name & $\underset{2-y e a r}{C}$ & $\underset{10-y e a r}{C}$ & $\underset{25-y e a r}{C}$ & $\underset{50-y e a r}{C}$ & $\underset{100-y e a r}{C}$ \\
\hline 01015700 & Houlton Brook near Oxbow & .07 & .08 & .09 & .08 & .08 \\
\hline 01017300 & Nichols Brook near Caribou & .07 & .10 & .12 & .12 & .13 \\
\hline 01021300 & Wiggins Brook near West Lubec & .17 & .17 & .20 & .19 & .19 \\
\hline 01026800 & Frost Pond near Sedgwick & .08 & .09 & .09 & .10 & .10 \\
\hline 01030300 & Trout Brook near Danforth & .11 & .14 & .16 & .16 & .16 \\
\hline 01031600 & Morrison Brook near Sebec Corners & .08 & .12 & .15 & .16 & .17 \\
\hline 01041900 & Mountain Brook near Lake Parlin & .07 & .10 & .11 & .12 & .13 \\
\hline 01049100 & Hall Brook at Thorndike & .10 & .17 & .22 & .24 & .26 \\
\hline 01049300 & North Branch Tanning Brook near Manchester & .10 & .12 & .13 & .13 & .14 \\
\hline 01050900 & Four Ponds Brook near Houghton & .04 & .06 & .06 & .07 & .07 \\
\hline 01062700 & Patte Brook near Bethel & .07 & .12 & .14 & .15 & .16 \\
\hline 01064200 & Mill Brook near Old Orchard & .09 & .12 & .15 & .15 & .17 \\
\hline 01066100 & Pease Brook near Cornish & .04 & .06 & .07 & .08 & .08 \\
\hline
\end{tabular}


Storm durations were assumed to be the time of concentration and were calculated with the empirical method derived by Kirpich (1940):

$$
t_{c}=0.0078 L_{c}^{0.77} / S_{c}^{0.385}
$$

where

$$
\begin{aligned}
& t_{c} \quad \begin{array}{l}
\text { is the time of concentration, in minutes; } \\
L_{c}
\end{array} \quad \begin{array}{l}
\text { is the length of the main channel from basin } \\
\text { divide to outlet, in feet; and }
\end{array} \\
& S_{c} \quad \begin{array}{l}
\text { is the average channel slope, in feet per feet, } \\
\text { calculated between points at } 10 \text { percent } \\
\text { and } 85 \text { percent of the main-channel length. }
\end{array}
\end{aligned}
$$

Slope and basin length for the selected basins were taken from Morrill (1975). Although the Kirpich method is based on data from six small agricultural basins and may or may not be appropriate for small forested drainage basins in Maine, the actual value of the time of concentration is not as important as its consistency and reproducibility when used in this probabilistic approach (Pilgrim, 1989).

The calculated $C$ values (table 11 ) ranged from 0.04 to 0.17 for the 2-year return-period $C$ value, and 0.07 to 0.26 for the 100-year $C$ value. The average $C$ values for the 2-, 10-, 25-, 50-, 100-year return periods were 0.084, 0.113, 0.132, 0.137 , and 0.143 , respectively. For comparison, the average of the traditional runoff coefficients calculated from land use and cover was 0.19 , more than twice $C_{2}$ and 1.3 times $C_{100}$. McCuen (1998) tabulated $C$ values for a variety of land covers and distinguished between values for return periods less than 25 years and 25 years or more. For undeveloped drainage basins as considered here, McCuen's ratios of $C_{25+} / C_{25-}$ typically range from 1.2 to 1.6. For the Probabilistic Rational Method developed here, $C_{100} / C_{10}=1.3$.

The 50-year $C$ values (table 11) were analyzed to see if they were related to the basin characteristics of the drainage basins. Basin-characteristic values for drainage-basin area and percentage of wetlands are from Hodgkins (1999), and main-channel length and main-channel slope are from Morrill (1975). The percentage of forested area in the drainage basins were calculated from geographic-information system (GIS) coverages. No significant correlations (Pearson's $\mathrm{r}, \mathrm{p}<0.05)$ were found between $C$ values and any of the drainage-basin characteristics. Geographic patterns in the $C$ values were not evident. The average $C$ value for each return period was used to compute the modeled peak flows from the Probabilistic Rational Method (table 12).

If the Probabilistic Rational Method is applied in the future to estimate peak flows for ungaged drainage basins in Maine with the average $C$ values developed in this study, parameters of the model (such as time of concentration and rainfall intensity) should be calculated in the same way as parameters used for developing the $C$ values. This is necessary because the $C$ values were developed using empirical methods. The Probabilistic Rational Method is not applicable to sites where regulation would appreciably affect the peak flows. A common definition of a regulated stream is one that has more than 4.5 million $\mathrm{ft}^{3}$ of usable reservoir storage per square mile. Usable storage is the volume of water normally available for release from a reservoir between the minimum and maximum controllable elevations. An amount of usable storage less than 4.5 million $\mathrm{ft}^{3}$ per square mile would, in general, affect peak flows by less than 10 percent (Benson, 1962). The average $C$ values of the Probabilistic Rational Method are probably not applicable to streams other those that drain rural basins. A commonly used definition of a rural drainage basin is one that has no more than 15 percent industrial, commercial, or residential land (Sauer and others, 1983).

\section{Comparison of Observed and Modeled Peak Flows for Selected Return Periods}

Peak flows from rainfall-runoff and statistical models were compared to observed peak flows for return periods of 2, 50, and 100 years at USGS streamflow-gaging stations on 17 streams in Maine and New Hampshire with drainage areas of 1.0 to 10 square miles. The observed peak flows (table 5) were compared to the modeled peak flows from the Rational Method (table 7), the NRCS TR-20 method (table 9), USGS regression equations (table 10), and the Probabilistic Rational Method (table 12).

The root mean square error (RMSE) was used as the overall measure of accuracy for the four methods of modeling peak flows for ungaged streams with drainage areas of 1.0 to $10 \mathrm{mi}^{2}$ (table 13). A lower RMSE indicates a better overall accuracy. The RMSE is computed as the square root of (the sum of the squared differences between the logarithms of the observed and modeled flows, divided by the number of streamflow-gaging stations). The RMSE is converted to percentage errors using equations from Riggs (1968). Approximately 68 percent of the modeled flows for each method are within the given percentages of the observed flows. The RMSE metric is described in more detail in the "Peak Flows at Crest-Stage Gaging Stations with Drainage Areas of 0.2 to 1.0 Square Miles: Comparison of Modeled and Observed Peak Flows" subsection of this report.

On the basis of the RMSE values in table 13, the USGS regression equations were the most accurate method of computing the peak flows in Maine for streams with drainage areas of 1.0 to $10 \mathrm{mi}^{2}$. The Probabilistic Rational Method was the next most accurate. The Rational Method and particularly the TR-20 method had much larger errors, especially for the 2-year peak flows. Mapped 50-year residuals (modeled minus observed peak flows) for the four methods of peak-flow estimation showed no obvious geographic patterns across Maine.

The errors in the Rational Method likely result from the runoff coefficient $(C)$ and time of concentration. It is unknown how well the $C$ values reflect the ratio of peak 
Table 12. Modeled peak flows using the Probabilistic Rational Method for basins in Maine and New Hampshire with drainage areas of 1.0 to 10 square miles.

$[\mathrm{ft} / \mathrm{s}$, cubic feet per second]

\begin{tabular}{|c|c|c|c|c|}
\hline $\begin{array}{c}\text { Streamflow- } \\
\text { gaging-station } \\
\text { number }\end{array}$ & Streamflow-gaging-station name & $\begin{array}{c}\text { 2-year } \\
\text { peak flow } \\
\left(\mathrm{ft}^{3} / \mathrm{s}\right)\end{array}$ & $\begin{array}{c}\text { 50-year } \\
\text { peak flow } \\
\left(\mathrm{ft}^{3} / \mathrm{s}\right)\end{array}$ & $\begin{array}{c}\text { 100-year } \\
\text { peak flow } \\
\left(\mathrm{ft}^{3} / \mathrm{s}\right)\end{array}$ \\
\hline 01014700 & Factory Brook near Madawaska, Maine & 228.4 & 787.3 & 931.8 \\
\hline 01015700 & Houlton Brook near Oxbow, Maine & 135.4 & 445.7 & 526.5 \\
\hline 01017300 & Nichols Brook near Caribou, Maine & 129.0 & 444.6 & 516.6 \\
\hline 01017900 & Marley Brook near Ludlow, Maine & 87.5 & 303.6 & 355.7 \\
\hline 01021300 & Wiggins Brook near West Lubec, Maine & 127.5 & 483.4 & 579.6 \\
\hline 01026800 & Frost Pond near Sedgwick, Maine & 182.6 & 597.6 & 714.0 \\
\hline 01030300 & Trout Brook near Danforth, Maine & 108.2 & 375.8 & 451.4 \\
\hline 01034900 & Coffin Brook near Lee, Maine & 100.8 & 342.7 & 397.7 \\
\hline 01049100 & Hall Brook at Thorndike, Maine & 183.2 & 609.4 & 722.7 \\
\hline 01049130 & Johnson Brook at South Albion, Maine & 151.5 & 499.8 & 575.2 \\
\hline 01049300 & North Branch Tanning Brook near Manchester, Maine & 61.4 & 200.0 & 235.0 \\
\hline 01050900 & Four Ponds Brook near Houghton, Maine & 214.4 & 675.0 & 812.5 \\
\hline 01062700 & Patte Brook near Bethel, Maine & 262.0 & 824.0 & 966.2 \\
\hline 01064200 & Mill Brook near Old Orchard, Maine & 86.0 & 295.9 & 341.5 \\
\hline 01066100 & Pease Brook near Cornish, Maine & 362.3 & $1,152.7$ & $1,338.9$ \\
\hline 01072850 & Mohawk Brook near Center Strafford, New Hampshire & 220.5 & 743.9 & 869.9 \\
\hline 01073600 & Dudley Brook near Exeter, New Hampshire & 214.9 & 699.1 & 820.0 \\
\hline
\end{tabular}

Table 13. Root-mean-square errors from comparison of modeled and observed peak 2-, 50-, and 100-year streamflows for basins in Maine and New Hampshire with drainage areas of 1.0 to 10 square miles.

[RMSE, root-mean-square error; NRCS, Natural Resources Conservation Service; USGS, U.S. Geological Survey]

\begin{tabular}{lcccccc}
\hline \multicolumn{1}{c}{ Method } & $\begin{array}{c}\text { RMSE } \\
\text { 2-year peak } \\
\text { flow } \\
\text { (log units) }\end{array}$ & $\begin{array}{c}\text { RMSE } \\
\text { 2-year peak } \\
\text { flow } \\
\text { (percentage) }\end{array}$ & $\begin{array}{c}\text { RMSE } \\
\text { 50-year peak } \\
\text { flow } \\
\text { (log units) }\end{array}$ & $\begin{array}{c}\text { RMSE } \\
\text { 50-year peak } \\
\text { flow } \\
\text { (percentage) }\end{array}$ & $\begin{array}{c}\text { RMSE } \\
\text { 100-year peak } \\
\text { flow } \\
\text { (log units) }\end{array}$ & $\begin{array}{c}\text { RMSE } \\
\text { 100-year peak } \\
\text { flow } \\
\text { (percentage) }\end{array}$ \\
\hline Rational & 0.516 & -69.5 to 228 & 0.358 & -56.1 to 128 & 0.349 & -55.2 to 123 \\
NRCS TR-20 & .922 & -88.0 to 735 & .627 & -76.4 to 323 & -628 & -191 \\
USGS Regression & .164 & -31.5 to 45.9 & .182 & -34.3 to 52.2 & -35.6 to 55.2 & -221 \\
Probabilistic Rational & .183 & -34.5 to 52.6 & .211 & -38.5 to 62.6 & -39.8 to 66.2 \\
\hline
\end{tabular}


flow to average rainfall intensity for selected return periods for different regions with different hydrologic regimes. The tabulated values of $C$ used in the Rational Method largely reflect judgment rather than hard data (Pilgrim and Cordery, 1993). The accuracy of the methods of computing time of concentration are largely unknown and also could be a major source of error.

The TR-20 method had larger errors than the Rational Method. The RMSE for the TR-20 method was heavily influenced by the error at one station, but the RMSE is still larger than the Rational Method RMSE if this station is removed from the error analyses. The TR-20 method is generally thought to be more accurate than the Rational Method because of its explicit consideration of the various factors that are thought to affect flood runoff. The limited testing of the TR-20 method, when it is used to compute peak flows of a given return period, however, casts some doubt on the accuracy and validity of this method (Pilgrim and Cordery, 1993). The poor performance of the TR-20 method is consistent with previous tests of this method (when it is used in a deterministic fashion); it has been tested extensively and has produced generally poor results. The problems are likely caused by the choice of curve number and (or) time of concentration (Pilgrim and Cordery, 1993). The assumption that $T$-year rainfall events cause $T$-year peak flows also may account for part of the large errors of these methods (Newton and Herrin, 1982).

The RMSE values for the USGS regression equations and the Probabilistic Rational Method do not represent validationtype errors. Most of the stations used in this comparison were used in the development of these methods. There was no independent set of data available to compute errors; however, no single site had much influence on the development of either method. Validation-type errors are probably slightly higher than the reported RMSE values. Validation-type errors for the 50-year peak-flow regression equations in Hodgkins (1999) were about three percentage points higher than the nonvalidation-type errors.

The modeled 50-year peak flows for each peakflow estimation method were plotted against the observed 50-year peak flows (figs. 3, 4, 5, 6). The spread of the data points about the line of equivalence in these plots gives a visual representation of the method errors. For example, the regression estimates (fig. 5) are much closer to the line than are the TR-20 estimates (fig. 4); both the TR-20 estimates and the regression estimates are relatively evenly distributed on either side of the line. The Rational Method (fig. 3) overpredicts most flows and the Probabilistic Rational Method (fig. 6) tends to overpredict peak flows from the smaller (less than 5-mi ${ }^{2}$ ) drainage basins and underpredict peak flows from larger drainage basins.

The results of this study are consistent with the most comprehensive analysis of observed and modeled peak streamflows in the United States. Newton and Herrin (1982) summarized an analysis of peak flows from 42 drainage basins in the Midwest and 28 in the Northwest. Drainagebasin areas ranged from 0.08 to $943 \mathrm{mi}^{2}$. Modeled peak flows from regression-based methods (including USGS regression equations) and rainfall-runoff-based methods (including the Rational Method and the NRCS TR-20 method) were tested against observed peak flows. USGS regression-based methods were found to be the most accurate and reproducible methods for estimating peak flows; the tested rainfall-runoff models did not perform well. 


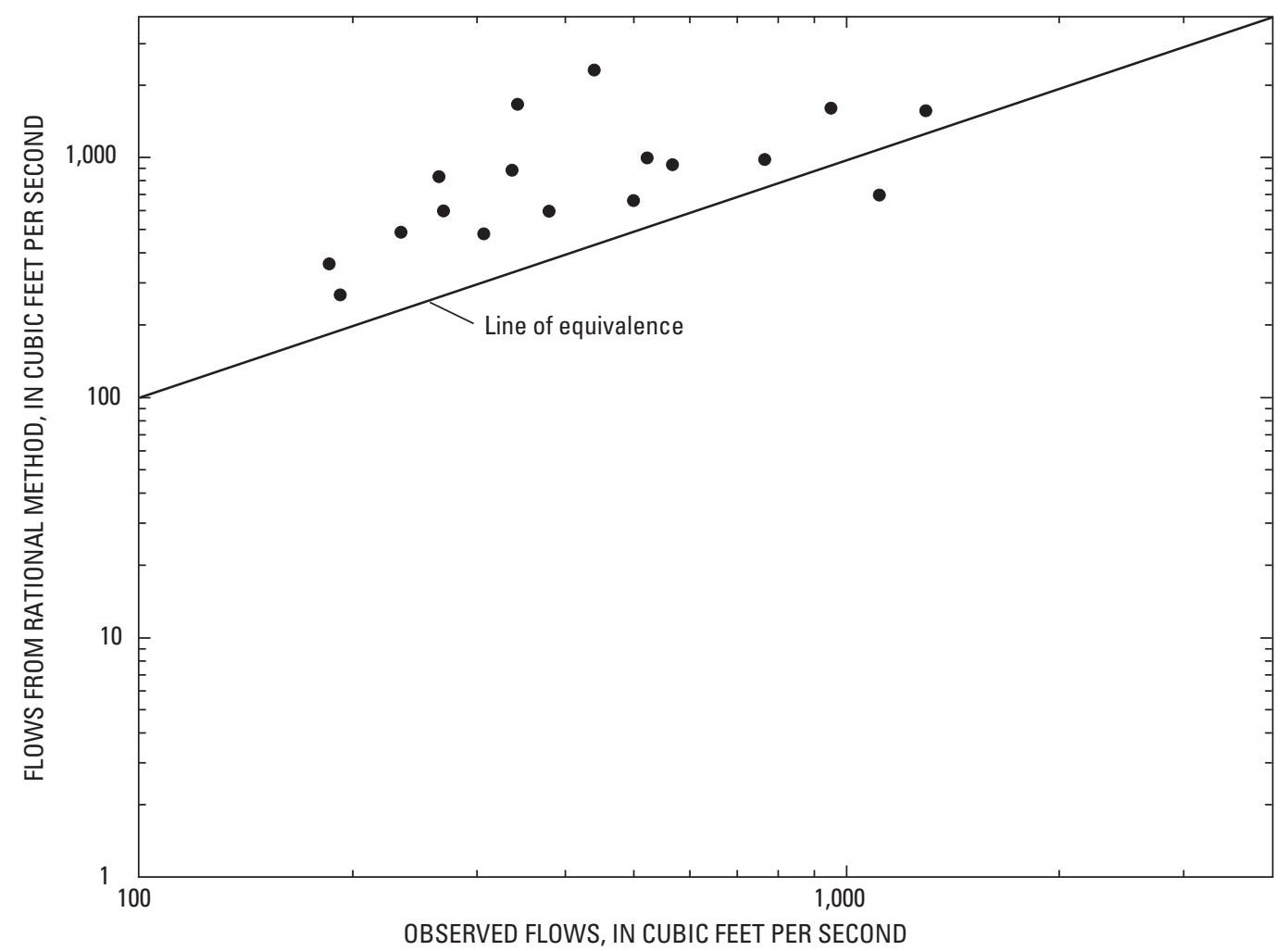

Figure 3. Modeled 50-year peak flows from the Rational Method plotted against observed 50-year peak flows.

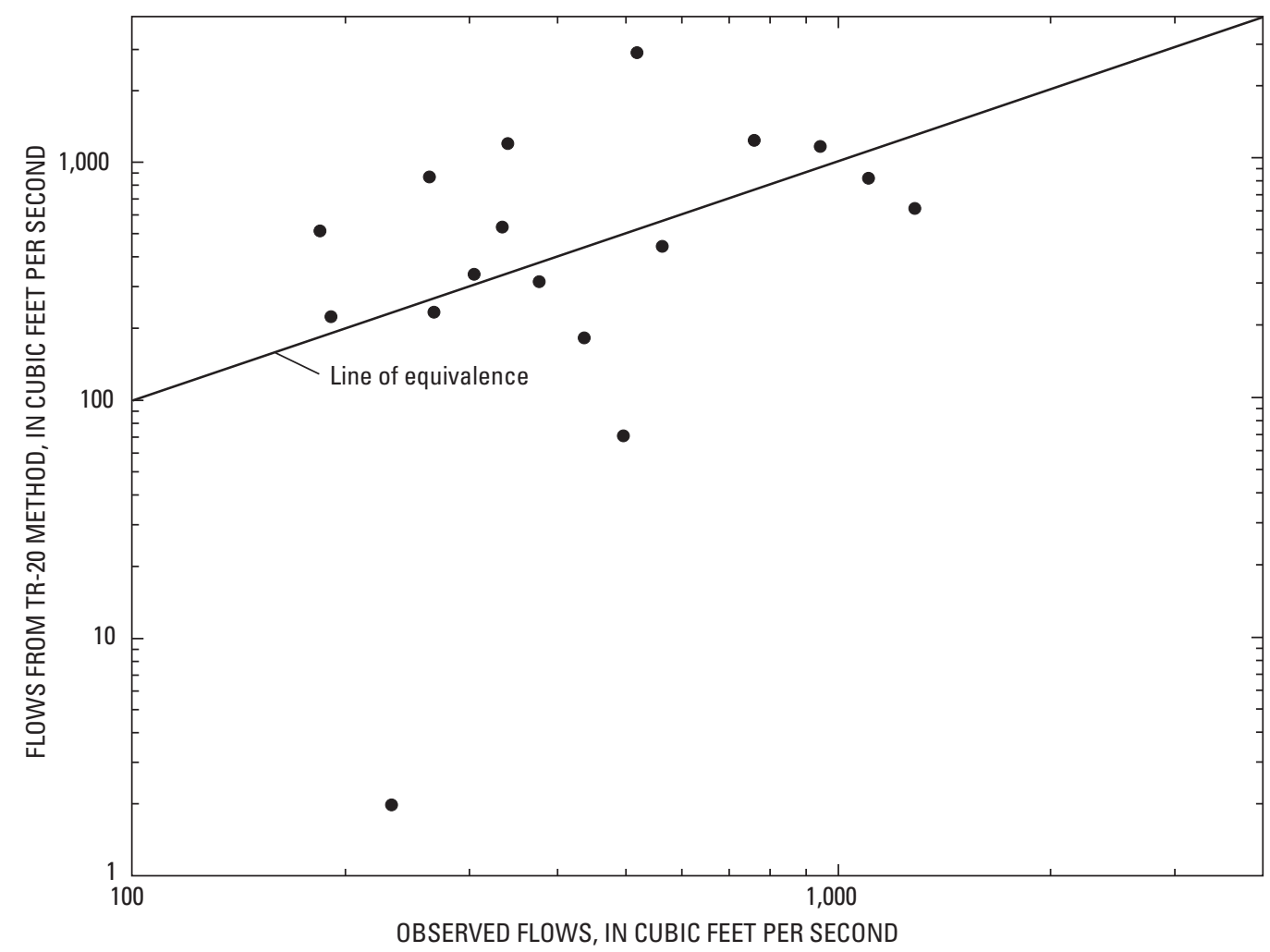

Figure 4. Modeled 50-year peak flows from the Natural Resources Conservation Service TR-20 method plotted against observed 50-year peak flows. 


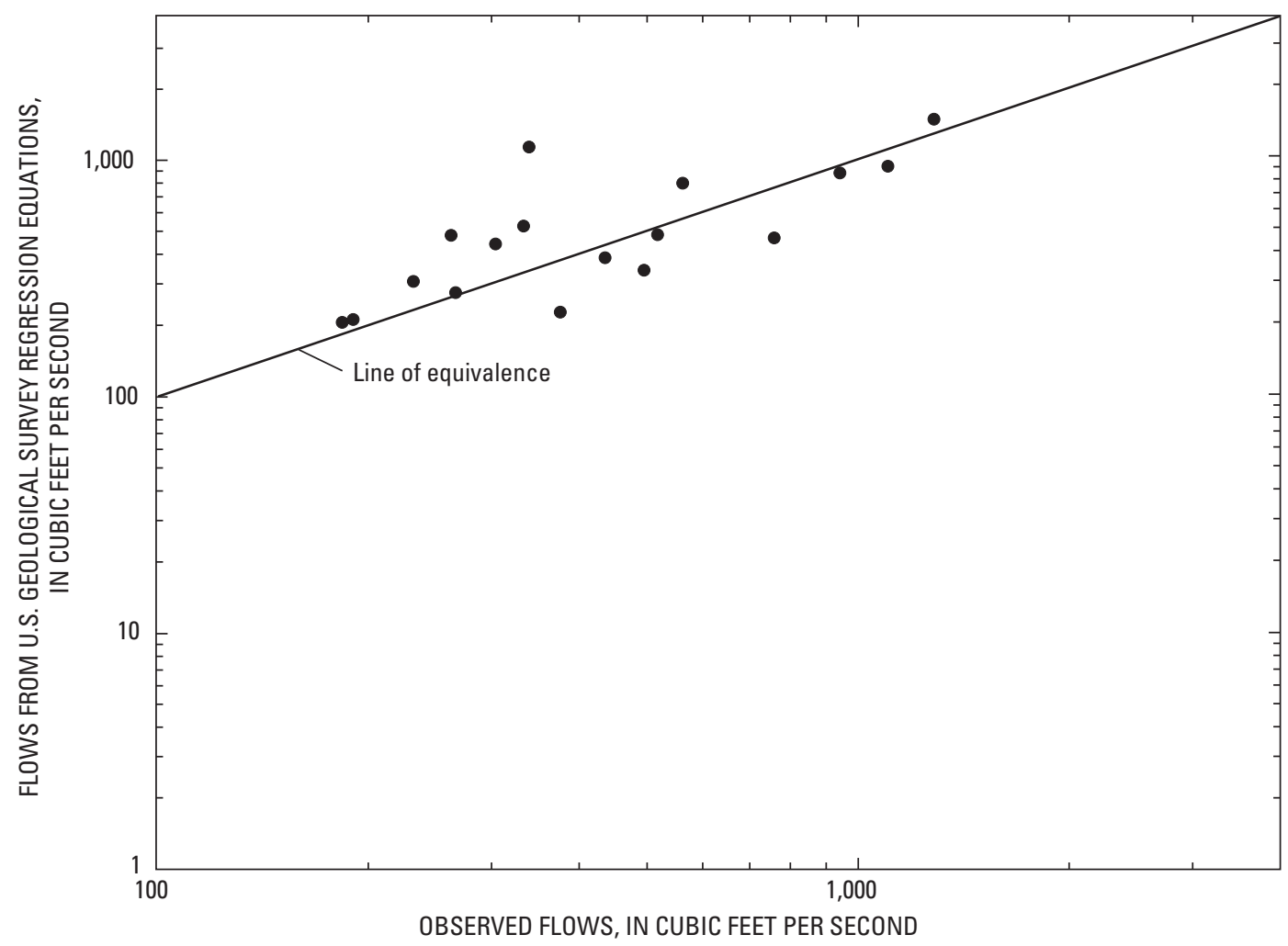

Figure 5. Modeled 50-year peak flows from U.S. Geological Survey regression equations plotted against observed 50-year peak flows.

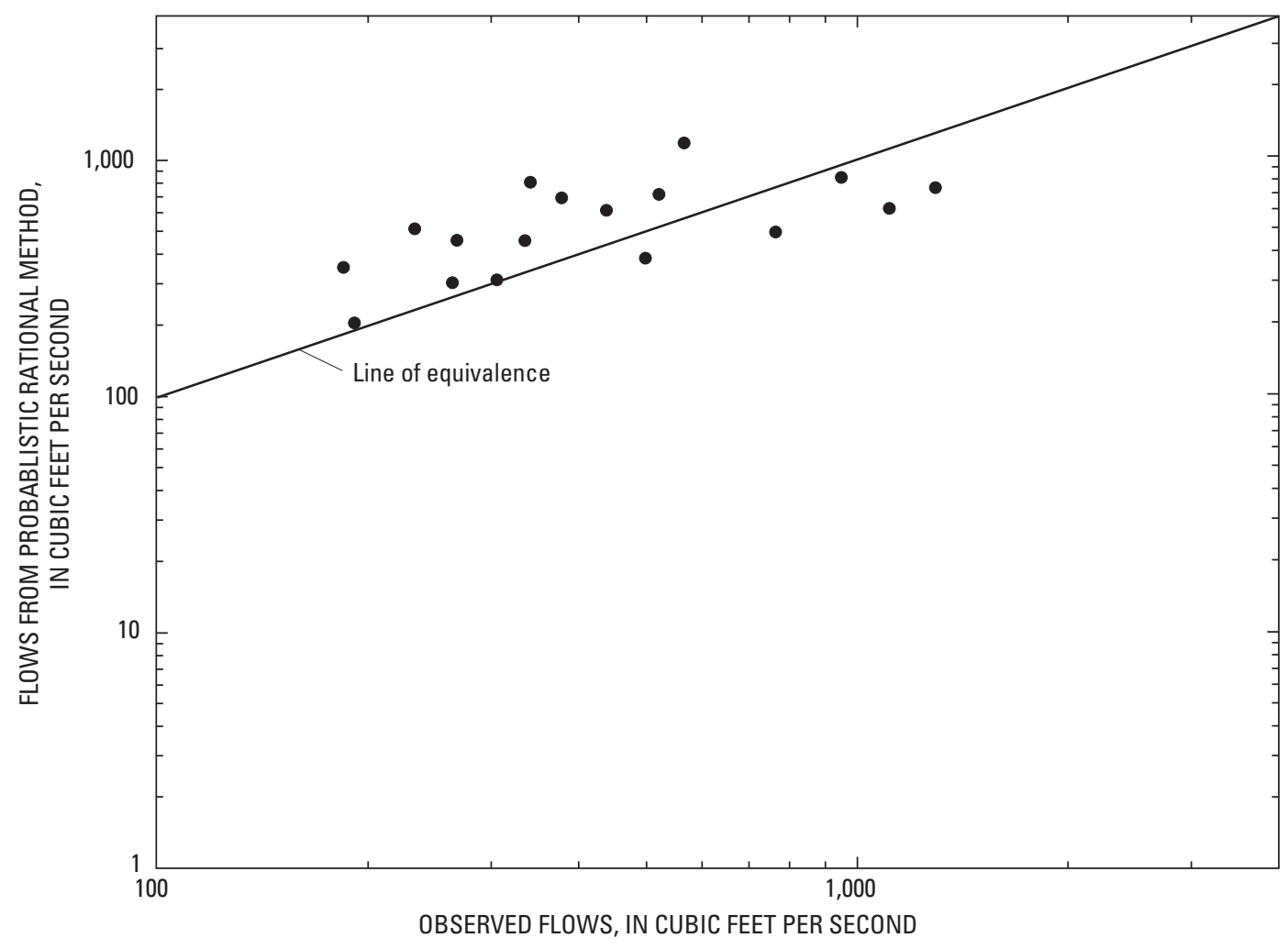

Figure 6. Modeled 50-year peak flows from the Probabilistic Rational Method plotted against observed 50-year peak flows. 


\section{Summary and Conclusions}

Estimates of peak flows on ungaged streams are used for the design of culverts, bridges, and other river structures. Maine Department of Transportation (MaineDOT) engineers and others who design hydraulic structures in and near streams need to know how well flood-estimation methods perform for peak flows of a given return period (such as the 50-year peak flow). The estimation of peak flows is probably most common and economically important on small (up to $10 \mathrm{mi}^{2}$ ) to medium (10 $\mathrm{mi}^{2}$ to $200 \mathrm{mi}^{2}$ ) rural drainage basins. Peak flows on streams that drain small ungaged drainage basins in Maine can be modeled by statistical methods, such as regression equations, and by simple rainfall-runoff models, such as the Rational Method and the Natural Resources Conservation Service (NRCS) TR-20 method. The U.S. Geological Survey and the MaineDOT began a cooperative study, starting with data collection in 1999 and 2000, to compare peak flows from statistical models and rainfall-runoff models to observed peak flows from streams with small drainage basins in Maine.

MaineDOT is interested in the accuracy of commonly used methods for estimating peak flows of given return periods for basins with drainage areas under $1.0 \mathrm{mi}^{2}$. It is currently not possible to evaluate this in Maine because long-term streamflow data exist for only three streams that drain basins of this size. For this reason, actual rainfall and associated peak flows were analyzed for basins with drainage areas of 0.2 to $1.0 \mathrm{mi}^{2}$ to determine the accuracy of the methods. Peak-flow data collection was started in 1999 and 2000 at 15 crest-stage gaging stations on streams across Maine with drainage-basin areas of 0.2 to $1.0 \mathrm{mi}^{2}$. After several additional years of data collection, these stations could be used to create regression equations applicable to the estimation of peak flows of given return periods for ungaged basins in Maine with drainage areas of this size.

The root-mean-square error (RMSE) was used as the overall measure of accuracy in this study. A lower RMSE indicates a better overall accuracy. Approximately 68 percent of the modeled flows for each method were within the given percentages of the observed flows. For example, if a method had an RMSE of -50 to 100 percent, about two thirds of modeled flows from that method would be within -50 to +100 percent of the observed flows.

Nine peak streamflows from actual rainfall events at four crest-stage gaging stations with drainage areas of 0.2 to $1.0 \mathrm{mi}^{2}$ were modeled by the Rational Method and the NRCS TR-20 method and compared to observed peak flows. These rainfall-runoff models were not calibrated to observed flows.
The Rational Method had an RMSE of -69.7 to 230 percent and TR-20 had an RMSE of -98.0 to 5,010 percent. Both the Rational Method and TR-20 underestimated the observed flows in most cases with the TR-20 method having much larger errors, on average.

The errors in the Rational Method may result from how the runoff coefficient $(C)$ is determined. It is unknown how well the $C$ values reflect the ratio of peak flow to average rainfall intensity (the assumed physical meaning of the $C$ values) for different regions with different hydrologic regimes. The TR-20 method had much larger errors than the Rational Method. The TR-20 method is generally thought to be more accurate than the Rational Method because of the explicit consideration of the various factors that are thought to affect flood runoff. The poor performance of the TR-20 method is consistent with previous tests of this method (when it is used in a deterministic fashion); it has been tested extensively and has produced generally poor results. Large errors may be caused by the choice of curve number.

Seventeen streams in Maine and adjoining areas of New Hampshire with drainage basins of 1.0 to $10 \mathrm{mi}^{2}$ have streamflow-gaging stations with enough long-term data to compute observed statistical peak flows of given return periods (such as the 50-year peak flow). Modeled peak flows from rainfall-runoff and statistical methods were compared to observed statistical peak flows with return periods of 2, 50, and 100 years from these drainage basins. Peak flows were modeled by the Rational Method, the NRCS TR-20 method, USGS regression equations, and the Probabilistic Rational Method. The Rational Method and TR-20 were not calibrated to observed flows.

The USGS regression equations were the most accurate method of computing peak flows in Maine for streams with drainage areas of 1.0 to $10 \mathrm{mi}^{2}$ (50-year RMSE of -34.3 to 52.2 percent). The Probabilistic Rational Method was the next most accurate ( -38.5 to 62.6 percent). The Rational Method (-56.1 to 128 percent) and particularly the TR-20 method (-76.4 to 323 percent) had much larger errors. Both the TR-20 and the regression estimates were relatively evenly split between underpredictions and overpredictions. The Rational Method overpredicted most flows and the Probabilistic Rational Method tended to overpredict peak flows from the smaller (less than 5-mi²) drainage basins and underpredict peak flows from the larger drainage basins. The results of this study are consistent with the most comprehensive analysis of observed and modeled peak streamflows in the United States (Newton and Herrin, 1982) that analyzed statistical peak flows from 70 drainage basins in the Midwest and the Northwest. 


\section{References Cited}

Benson, M.A., 1962, Factors influencing the occurrence of floods in a humid region of diverse terrain: U.S. Geological Survey Water-Supply Paper 1580-B, 64 p.

Dooge, J.C.I., 1973, Linear theory of hydrologic systems: Washington, DC, Agricultural Research Service, U.S. Department of Agriculture, Technical Bulletin 1468, 327 p.

Dunne, Thomas, and Leopold, L. B., 1978, Water in environmental planning: San Francisco, California, W. H. Freeman and Company, $818 \mathrm{p}$.

French, R., Pilgrim, D.H., and Laurenson, E.M., 1974, Experimental examination of the Rational Method for small, rural catchments: Civil Engineering Transactions, Institution of Engineers, Australia, v. CE16, p. 95-102.

Fulford, J.M., 1995, User's guide to the culvert analysis program: U.S. Geological Survey Open-File Report 95-137, $69 \mathrm{p}$.

Hayes, D.C., and Young, R.L., 2006, Comparison of peak discharge and runoff characteristic estimates from the Rational Method to field observations for small basins in central Virginia: U.S. Geological Survey Scientific Investigations Report 2005-5254, 38 p.

Hodgkins, G.A., 1999, Estimating the magnitude of peak flows for streams in Maine for selected recurrence intervals: U.S. Geological Survey Water-Resources Investigations Report 99-4008, 45 p.

Horner, W.W., and Flynt, F.L., 1936, Relation between rainfall and runoff from small urban areas: Transactions of the American Society of Civil Engineers, v. 101, p.140-183.

HydroCAD Software Solutions LLC, 2004, HydroCad, Version 7, P.O. Box 350, Chocorua, NH.

Kirpich, Z.P., 1940, Time of concentration of small agricultural watersheds: Civil Engineering, American Society of Civil Engineers, v. 10, p. 362.

LeBlanc, D.R., 1978, Progress report on hydrologic investigations of small drainage areas in New HampshirePreliminary relations for estimating peak discharges on rural, unregulated streams: U.S. Geological Survey WaterResources Investigations Report 78-47, 9 p.

Maine Department of Environmental Protection, 1995, Stormwater management for Maine: Best Management Practices, Augusta, Maine.

McCuen, R.H., 1998, Hydrologic analysis and design: Upper Saddle River, NJ, Prentice Hall, 814 p.

Morrill, R.A., 1975, A technique for estimating the magnitude and frequency of floods in Maine: U.S. Geological Survey Open-File Report 75-292, 44 p.
National Oceanic and Atmospheric Administration, 2002, Climatography of the United States No. 81-Monthly station normals of temperature, precipitation, and heating and cooling degree days, 1971-2000-Region 17, Maine, $16 \mathrm{p}$.

National Weather Service, 1989, National Weather Service observing handbook no. 2, Cooperative station observations, July, 1989: Silver Spring, Maryland, 83 p.

Natural Resources Conservation Service, 1985-2000, National Engineering Handbook, Part 630, Hydrology.

Natural Resources Conservation Service, 1986, Urban hydrology for small watersheds: Washington, DC, Technical Release 55.

New Hampshire Department of Transportation, 1998, Manual on Drainage Design for Highways: Concord, New Hampshire.

Newton, D.W., and Herrin, J.C., 1982, Assessment of commonly used methods of estimating flood frequency: Transportation Research Record 896, p. 10-30.

Pilgrim, D.H., 1989, Regional methods for estimation of design floods for small to medium sized drainage basins in Australia, in M. L. Kavvas, ed., New directions in surface water modeling: IAHS Publication 181, p. 247-260.

Pilgrim, D.H., and Cordery, I., 1993, Flood Runoff, in Maidment, D.R., ed., Handbook of Hydrology: New York, McGraw-Hill Inc., p. 9.1-9.42.

Pilgrim, D.H., McDermott, G.E., and Mittelstadt, G.E., 1989, Development of the Rational Method for flood design for small rural basins in Australia, in B.B. Yen, ed., Channel flow and catchment runoff: Charlottesville, Va., Department of Civil Engineering, University of Virginia, p. 51-60.

Ponce, V.M., 1989, Engineering Hydrology—Principles and practices: Englewood Cliffs, NJ, Prentice-Hall.

Randall, A.D., 2001, Hydrogeologic framework of stratifieddrift aquifers in the glaciated northeastern United States: U.S. Geological Survey Professional Paper 1415-B, 179 p.

Rantz, S.E., and others, 1982, Measurement and computation of streamflow: U.S. Geological Survey Water-Supply Paper 2175, 2 v., $631 \mathrm{p}$.

Riggs, H.C., 1968, Some statistical tools in hydrology: U.S. Geological Survey Techniques of Water-Resources Investigations, book 4, chapter A1, $39 \mathrm{p}$.

Sauer, V.B., Thomas, W.O., Jr., Stricker, V.A., and Wilson, K.V., 1983, Flood characteristics of urban watersheds in the United States: U.S. Geological Survey Water-Supply Paper 2207, 63 p.

State of Maine, 2005, State of Maine urban and arterial highway design guide, chapter 12-Drainage Design: Augusta, Maine, Maine Department of Transportation. 


\section{Appendix 1: Methods for Estimation of Time of Concentration}

\section{Contents}

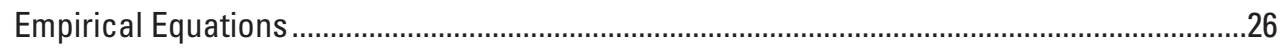

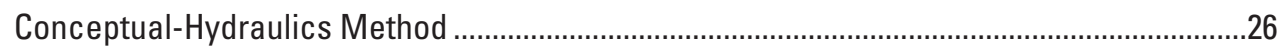

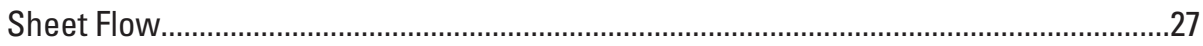

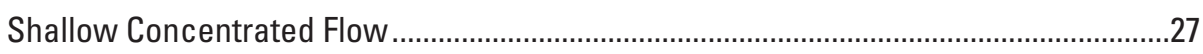

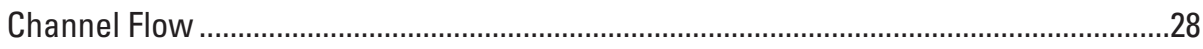

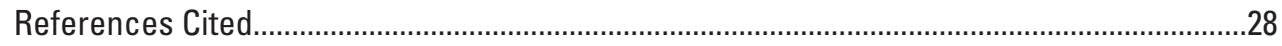


Time of concentration is a critical drainage-basin parameter for peak-flow estimation by rainfall-runoff modeling. Two approaches are commonly used for estimating time of concentration: empirical equations and a conceptual-hydraulics method.

\section{Empirical Equations}

McCuen (1998) and Pilgrim and Cordery (1993) summarize a number of commonly used equations for time of concentration. Some of the equations were developed for urban drainage basins and thus are inappropriate for this study. The Kirpich and Kerby-Hathaway (K-H) equations were derived for small undeveloped drainage basins. Although the equations are empirical, they are simple in form and utilize just a few basic input parameters.

The Kirpich equation (Kirpich, 1940) is used to calculate total drainage basin time of concentration as

$$
t_{c}=0.0078 L_{c}^{0.77} / S_{c}^{0.385},
$$

where

$$
\begin{array}{cl}
t_{c} & \text { is time of concentration, in minutes; } \\
L_{c} & \text { is channel flow-path length, in feet; and } \\
S_{c} & \text { is channel flow-path slope, in feet per feet. }
\end{array}
$$

This equation was developed from data on small drainage basins ( 1 acre-112 acres) in Tennessee with slopes between 0.03 and $0.10 \mathrm{ft} / \mathrm{ft}$. Kirpich also developed an equation for Pennsylvania, but with different powers and coefficients. Care should always be exercised when applying empirical relationships to situations greatly different from those used to develop the equations.

The Kerby-Hathaway (K-H) equation was developed from data on very small (less than 10 acres) drainage basins dominated by surface flow. Thus, it is best suited for small drainage basins or the sheet-flow component of larger drainage basins:

$$
t_{c}=0.83\left(n L / S^{0.5}\right)^{0.47},
$$

where

$$
\begin{array}{ll}
t_{c} & \text { is time of concentration, in minutes; } \\
n & \text { is Manning's roughness coefficient; } \\
S & \text { is flow-path slope, in feet per feet; and } \\
L & \text { is flow-path length, in feet. }
\end{array}
$$

The $n L / S^{0.5}$ term is based on Manning's equation; the leading coefficient and exponent were fit empirically. The major difference between the $\mathrm{K}-\mathrm{H}$ and Kirpich equations is that the K-H equation explicitly treats the roughness $n$ as in Manning's equation. In Kirpich, roughness is absorbed into the leading coefficient.

\section{Conceptual-Hydraulics Method}

In the conceptual-hydraulics method, the hydraulically longest flow path must be delineated before time of concentration can be calculated. A short distance over a flat, rough area may have a longer traveltime than one over a long but steep and smooth area. As a practical matter, flow paths are usually determined on the basis of physical length. This conceptual-hydraulics method is commonly referred to as the "TR-55 approach" after the NRCS (1986) model by which it is most familiar.

A raindrop starting at the hydraulically most remote point in the drainage basin is assumed to follow a flow path that consists of some combination of sheet flow, shallow concentrated flow, and channel flow, usually in that order. All three types of flow need not be present. Manning's equation for open channel flow is typically used to calculate the traveltime $\left(T_{t}\right)$ of flow in each flow segment. The sum of component traveltimes gives the drainage basin time of concentration $\left(t_{c}\right)$ :

$$
t_{c}=T_{t \mid \text { sheet }}+T_{t \mid c o n c}+T_{t \mid c h a n n e l}
$$

Because the calculations are based on open-channel flow hydraulics, parameters that have some nominal physical basis are used: roughness $(n)$, slope $(S)$, hydraulic radius ( $R_{h}$, surrogate for depth of flow), and flow length $(L)$. Although these parameters are physically meaningful and are not empirical coefficients determined by regression, their determination, in practice, can be subjective.

The traveltimes are calculated from the basic definition of velocity:

$$
v=L / T_{t} \text {, reordered to obtain }
$$

$$
T_{t}=L / v .
$$

Manning's equation (in consistent-length units and time in seconds) is used to calculate velocity:

$$
v=\beta R_{h}^{2 / 3} S^{1 / 2} / n,
$$

where

$\begin{array}{cl}v & \text { is velocity, in feet per second; } \\ \beta & \text { is a unit-conversion factor (1.486 for U.S. } \\ \text { Customary units } 1 \text { for metric units); } \\ R_{h} & \text { is hydraulic radius, in feet }=A_{\text {flow }} / P_{\text {wet }} \\ A_{\text {flow }} & \text { is flow cross-sectional area, in square feet; } \\ P_{\text {wet }} & \text { is wetted-flow perimeter, in feet; } \\ S & \text { is slope, in feet per feet; and } \\ n & \text { is Manning's roughness parameter. }\end{array}$




\section{Sheet Flow}

Sheet flow (or overland flow) is flow over planar surfaces such as paved areas and fields. The typical assumption is that it occurs primarily in drainage-basin upland areas. With sheet flow, Manning's $n$ is an effective roughness coefficient that includes the effect of raindrop impact, drag over the surface, obstacles to flow (such as litter, crop ridges, rocks), and erosion and transport of sediment. Appropriate $n$ values range from 0.01 for smooth paved surfaces to 0.40 for forest floors. Flow depth (hydraulic radius $R_{h}$ ) should ordinarily not exceed 2 in. Welle and Woodward (1986) cite a mean depth of 0.002 $\mathrm{ft}$ for paved surfaces and $0.02 \mathrm{ft}$ for vegetated surfaces.

Sheet flow is often the "slowest" flow component in the TR-55 conceptual-hydraulic model, especially in small drainage basins. Thus, overall drainage basin time of concentration is sensitive to the sheet-flow parameters. Length of sheet flow is a particular issue. A value of $300 \mathrm{ft}$ is cited in TR-55 as being an upper limit, but this value has crept into practice as a default standard. In fact, this value is probably too large in most situations, and is possibly justified only for flat, uniform surfaces. Welle and Woodward (1986) recommend $100 \mathrm{ft}$ for vegetated surfaces, and values up to $300 \mathrm{ft}$ may be appropriate for paved surfaces. Large flow lengths lead to overestimation of time of concentration, underestimation of rainfall intensity $i$, underestimation of the design flow, and ultimately underdesign of the hydraulic structure. Long sheet-flow lengths also imply unrealistically large flow depths.

A good algorithm for sheet flow is the Kinematic Wave (KW) approach, which in turn is based on Manning's equation. The KW expression for traveltime $\left(T_{\mathrm{t} \text { sheet }}\right)$ is derived from the general velocity method by assuming that the depth of sheet flow (essentially the hydraulic radius) is equal to the product of rain intensity and time of concentration for duration $t_{d}>T_{\mathrm{t} \mid \text { sheet }}$ :

$$
R_{h}=i T_{t \mid \text { sheet }}
$$

Substituting into Manning's equation gives

$$
v=\beta\left(i T_{t \mid \text { sheet }}\right)^{2 / 3} S^{1 / 2} / n
$$

Continuing with the velocity expression for sheet-flow traveltime and solving for $T_{t \mid \text { sheet }}$ gives

$$
T_{t \mid \text { heet }}=L / v=\left(n L / \beta S^{0.5}\right)^{0.6} / i^{0.4} \text {, }
$$

where all physical quantities are in consistent length and time units. For the familiar units of inches per hour for $i$, feet for $L$, and minutes for $T_{\mathrm{t} \text { sheet }}$, the equation becomes

$$
T_{t \mid \text { sheet }}=0.94\left(n L / S^{0.5}\right)^{0.6} / i^{0.4}
$$

The factor $\left(n L / S^{0.5}\right)^{0.6}$ is a drainage-basin parameter, and 0.94 lumps several conversion factors.
This is a nonlinear equation and requires iterative solution for $T_{t \mid \text { sheet }}$ because intensity $i$ is a function of rainfall duration (set equal to the time of concentration). This equation is solved using standard computer-based root-finding methods.

A simplified variant of the KW time-of-concentration equation (Natural Resources Conservation Service, 1986), henceforth referred to as the TR-55 equation, is

$$
T_{t \mid \mathrm{sheet}}=\left(0.42 / P^{0.5}\right)\left(n L / S^{0.5}\right)^{0.8}
$$

where $\mathrm{P}$ is the 24-hour design-rainfall depth for a specified return period and the equation units are feet, inches, and minutes. This is essentially a linearization of the KW traveltime equation based on NRCS dimensionless rainfall hyetographs. It is common practice to specify the 2-year 24-hour storm depth, although it is better to use the storm depth corresponding to the actual return period of design interest. The K-H and TR-55 approximate methods are quite similar because both are based on Manning's equation.

Comparing Kirpich, K-H, and KW (or equivalently TR-55) methods, KW includes the effect of rainfall intensity on time of concentration. $\mathrm{KW}$ is consistent with the theoretical and intuitive expectation that flows from a small drainage basin will peak sooner when subject to more intense rainfall, all other things being equal, and is likely to be more accurate than the Kirpich or K-H equations for estimating time of concentration. The effect of sheet-flow time of concentration on total basin time of concentration diminishes as a drainage basin gets bigger because the dominant component becomes channel flow.

\section{Shallow Concentrated Flow}

Shallow concentrated flow commences at the point where sheet flow is too inefficient to transport the volume of water originating upstream of that point. Shallow concentrated flow is visualized as occurring in numerous and closely spaced small channels and rivulets. Depth of flow is still small, but Manning's $n$ is smaller than in sheet flow, making for faster flow velocity and shorter traveltimes as compared to sheet flow. In agricultural areas, tillage will control the direction of flow, in which case aerial photographs and site inspections are essential. Values of 2 to 6 in. for $R_{h}$ and 0.05 for $n$ are reasonable starting estimates.

TR-55 methodology offers a simplification of Manning's equation, whereby hydraulic geometry and roughness are lumped into a conveyance-like velocity factor $k_{v}$ in feet per second:

$$
k_{v}=\beta R_{h}^{2 / 3 / n}
$$

and

$$
v=k_{v} S^{1 / 2} .
$$


This formulation recognizes that $R_{h}$ and $n$ are difficult to estimate in a physically meaningful manner for actual field situations. Instead, $k_{v}$ has been determined for a variety of land-cover types (woodland, 5; bare soil, 10; grasses, 15; paved, 20).

\section{Channel Flow}

Open channels are assumed to begin where surveyed cross-section information has been obtained, where channels and singular drainage features are visible on aerial photographs, or where blue lines (indicating streams) appear on USGS topographic maps. In general, the use of aerial photographs will result in longer channels than the use of USGS topographic maps alone. Both Manning's $n$ and $R_{h}$ are channel-specific and should be based on actual observation and measurement. Standard practice in hydrologic studies is to base hydraulic radius on bankfull conditions (approximately the 2-year event), even though the 50-year design event will be over the bank with a significantly different hydraulic geometry. Roadside ditches are treated as open channels.

It should be noted that for NRCS TR-20 modeling, this channel-flow component refers to a channel segment with a subdrainage basin unit, as distinct from larger main-channel segments that are treated separately from runoff-generating subdrainage basins. These larger segments are modeled with hydrologic routing algorithms in TR-20; in more complex models they may be simulated with the St. Venant equations of motion. Thus, it may be inferred that channel-flow segments within subdrainage basins tend to be small, and larger channels are modeled as distinct elements.

\section{References Cited}

Kirpich, Z.P., 1940, Time of concentration of small agricultural watersheds: Civil Engineering, American Society of Civil Engineers, v. 10, p. 362.

McCuen, R.H., 1998, Hydrologic analysis and design: Upper Saddle River, NJ, Prentice Hall, 814 p.

Natural Resources Conservation Service, 1986, Urban hydrology for small watersheds: Washington, DC, Technical Release 55.

Pilgrim, D.H., and Cordery, I., 1993, Flood Runoff, in Maidment, D.R., ed., Handbook of Hydrology: New York, McGraw-Hill Inc., p. 9.1-9.42.

Welle, P., and Woodward, D., 1986, Time of concentration: Natural Resources Conservation Service Hydrology Technical Note No. N4. 


\section{Appendix 2: Additional Data Used in the Rational Method and Natural Resources Conservation Service TR-20 Methods}

\section{Tables}

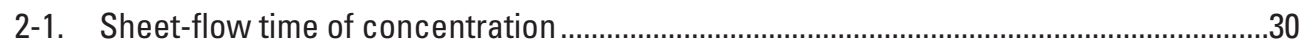

2-2. Shallow-concentrated-flow time of concentration .........................................................31

2-3. Channel-flow-segment time of concentration...............................................................32 


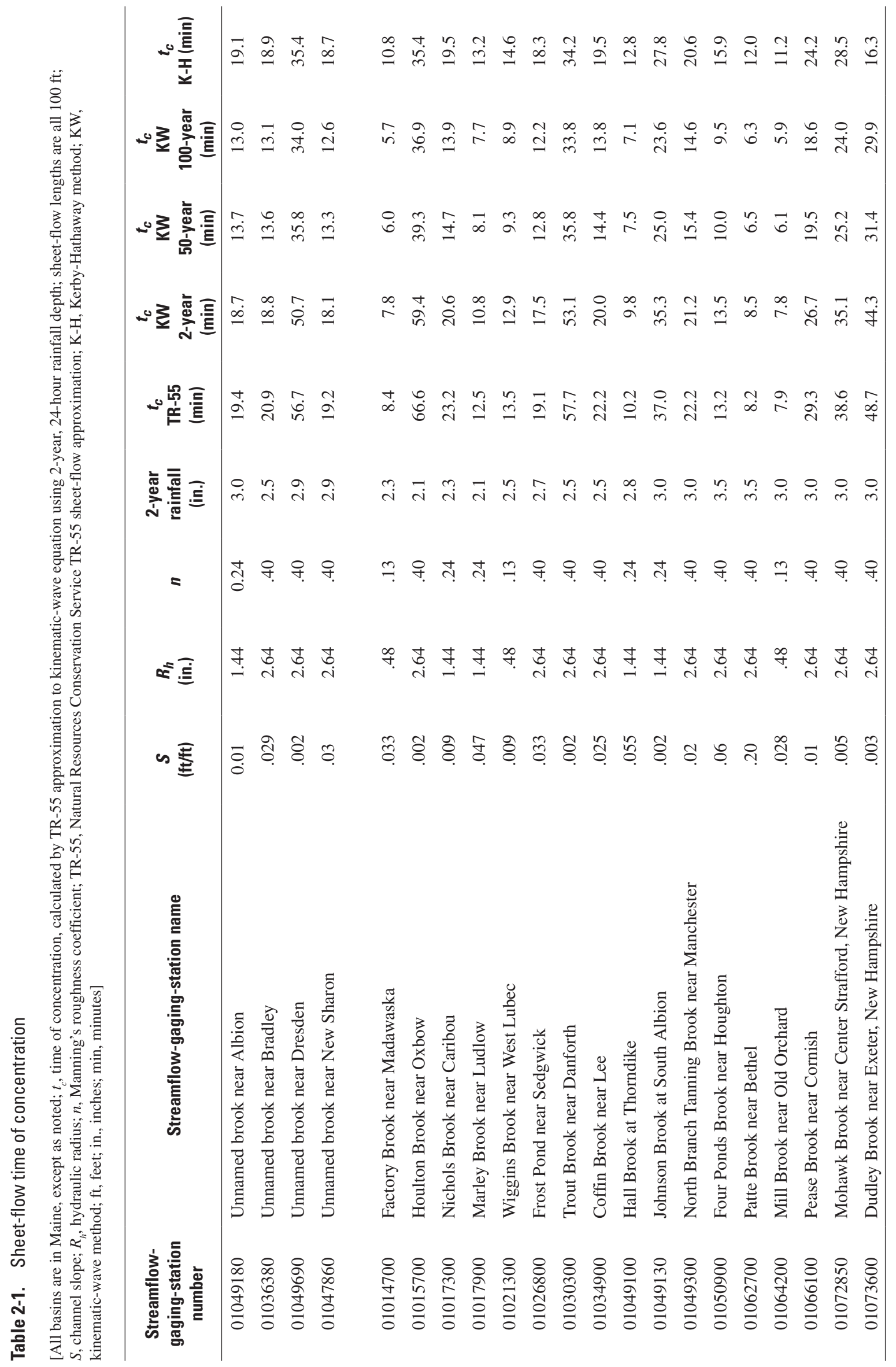


Table 2-2. Shallow-concentrated-flow time of concentration

[All basins are in Maine, except as noted; all flow lengths are $150 \mathrm{ft} ; S$, channel slope; $R_{h}$, hydraulic radius; $n$, Manning's roughness coefficient; $k v$, velocity factor; $t$, time of concentration; ft, feet; in., inches; min, minutes; $s$, seconds; $V$, velocity]

\begin{tabular}{|c|c|c|c|c|c|c|c|}
\hline $\begin{array}{l}\text { Streamflow- } \\
\text { gaging station } \\
\text { number }\end{array}$ & Streamflow-gaging station name & $\underset{(\mathrm{ft} / \mathrm{tt})}{S}$ & $\begin{array}{c}R_{h} \\
\text { (in.) }\end{array}$ & $n$ & $\begin{array}{c}k v \\
(\mathrm{ft} / \mathrm{s})\end{array}$ & $\begin{array}{c}t_{c} \\
(\min )\end{array}$ & $\begin{array}{c}V \\
(\mathrm{ft} / \mathrm{s})\end{array}$ \\
\hline 01049180 & Unnamed brook near Albion & 0.007 & 2.64 & 0.11 & 5.0 & 6.1 & 0.4 \\
\hline 01036380 & Unnamed brook near Bradley & .029 & 2.64 & .11 & 5.0 & 3.0 & .8 \\
\hline 01049690 & Unnamed brook near Dresden & .002 & 2.64 & .11 & 5.0 & 11.2 & .2 \\
\hline 01047860 & Unnamed brook near New Sharon & .030 & 2.64 & .11 & 4.92 & 2.9 & .9 \\
\hline 01014700 & Factory Brook near Madawaska & .033 & 2.64 & .4 & 1.35 & 10.2 & .2 \\
\hline 01015700 & Houlton Brook near Oxbow & .002 & 2.64 & .4 & 1.35 & 19.5 & .1 \\
\hline 01017300 & Nichols Brook near Caribou & .009 & 2.64 & .4 & 1.35 & 41.3 & .1 \\
\hline 01017900 & Marley Brook near Ludlow & .047 & .48 & .025 & 6.94 & 1.7 & 1.5 \\
\hline 01021300 & Wiggins Brook near West Lubec & .009 & .48 & .025 & 6.94 & 3.8 & .7 \\
\hline 01026800 & Frost Pond near Sedgwick & .033 & 2.64 & .4 & 1.35 & 10.2 & .2 \\
\hline 01030300 & Trout Brook near Danforth & .002 & 2.64 & .4 & 1.35 & 38.5 & .1 \\
\hline 01034900 & Coffin Brook near Lee & .025 & 2.64 & .4 & 1.4 & 11.7 & .2 \\
\hline 01049100 & Hall Brook at Thorndike & .055 & 2.64 & .4 & 1.35 & 7.9 & .3 \\
\hline 01049130 & Johnson Brook at South Albion & .002 & 2.64 & .095 & 5.7 & 9.8 & .3 \\
\hline 01049300 & North Branch Tanning Brook near Manchester & .020 & 2.64 & .4 & 1.35 & 13.1 & .2 \\
\hline 01050900 & Four Ponds Brook near Houghton & .060 & 2.64 & .4 & 1.35 & 7.5 & .3 \\
\hline 01062700 & Patte Brook near Bethel & .200 & 2.64 & .4 & 1.35 & 4.1 & .6 \\
\hline 01064200 & Mill Brook near Old Orchard & .047 & .48 & .025 & 6.94 & 1.7 & 1.5 \\
\hline 01066100 & Pease Brook near Cornish & .030 & 2.8 & .4 & 1.4 & 10.3 & .3 \\
\hline 01072850 & Mohawk Brook near Center Strafford, New Hampshire & .005 & 2.8 & .4 & 1.4 & 25.1 & .1 \\
\hline 01073600 & Dudley Brook near Exeter, New Hampshire & .003 & 2.8 & .4 & 1.4 & 33.6 & .1 \\
\hline
\end{tabular}


Table 2-3. Channel-flow-segment time of concentration

[All basins are in Maine, except as noted; $L$, channel length; $S$, channel slope; $R_{h}$, hydraulic radius; $n$, Manning's roughness coefficient; $t_{c}$, time of concentration; ft, feet; in., inches; min, minutes; $s$, seconds; $V$, velocity]

\begin{tabular}{|c|c|c|c|c|c|c|c|}
\hline $\begin{array}{l}\text { Streamflow- } \\
\text { gaging station } \\
\text { number }\end{array}$ & Streamflow-gaging station name & $\underset{(f t)}{L}$ & $\underset{(\mathrm{ft} / \mathrm{ft})}{S}$ & $\begin{array}{c}R_{h} \\
(f t)\end{array}$ & $n$ & $\begin{array}{c}t_{c} \\
(\mathbf{m i n})\end{array}$ & $\underset{(\mathrm{ft} / \mathrm{s})}{\boldsymbol{V}}$ \\
\hline 01049180 & Unnamed brook near Albion & 8,289 & 0.020 & 0.7 & 0.04 & 32.7 & 4.2 \\
\hline 01036380 & Unnamed brook near Bradley & 7,373 & .010 & .7 & .04 & 41.2 & 3.0 \\
\hline 01049690 & Unnamed brook near Dresden & 5,242 & .039 & .7 & .04 & 14.6 & 6.0 \\
\hline 01047860 & Unnamed brook near New Sharon & 6,828 & .013 & .7 & .04 & 33.0 & 3.5 \\
\hline 01014700 & Factory Brook near Madawaska & 17,440 & .029 & 3.6 & .04 & 19.7 & 14.7 \\
\hline 01015700 & Houlton Brook near Oxbow & 16,837 & .003 & 4.4 & .04 & 48.8 & 5.8 \\
\hline 01017300 & Nichols Brook near Caribou & 21,902 & .012 & 3.6 & .04 & 38.2 & 9.6 \\
\hline 01017900 & Marley Brook near Ludlow & 11,798 & .036 & 3.4 & .04 & 12.3 & 16.0 \\
\hline 01021300 & Wiggins Brook near West Lubec & 27,335 & .004 & 4.9 & .04 & 64.1 & 7.1 \\
\hline 01026800 & Frost Pond near Sedgwick & 11,750 & .026 & 2.9 & .04 & 15.9 & 12.3 \\
\hline 01030300 & Trout Brook near Danforth & 28,991 & .002 & 4.4 & .04 & 110.8 & 4.4 \\
\hline 01034900 & Coffin Brook near Lee & 14,596 & .014 & .7 & .04 & 68.9 & 3.5 \\
\hline 01049100 & Hall Brook at Thorndike & 28,927 & .022 & .7 & .04 & 107.4 & 4.5 \\
\hline 01049130 & Johnson Brook at South Albion & 16,803 & .016 & 2.6 & .04 & 14.2 & 7.1 \\
\hline 01049300 & North Branch Tanning Brook near Manchester & 10,353 & .027 & 2.9 & .04 & 13.8 & 12.5 \\
\hline 01050900 & Four Ponds Brook near Houghton & 10,514 & .012 & 2.9 & .04 & 21.0 & 8.4 \\
\hline 01062700 & Patte Brook near Bethel & 27,500 & .038 & 4.9 & .04 & 21.9 & 20.9 \\
\hline 01064200 & Mill Brook near Old Orchard & 17,009 & .004 & 4.4 & .04 & 42.7 & 6.6 \\
\hline 01066100 & Pease Brook near Cornish & 16,463 & .026 & 5.3 & .04 & 15.0 & 18.3 \\
\hline 01072850 & Mohawk Brook near Center Strafford, New Hampshire & 26,392 & .047 & 5.3 & .04 & 17.9 & 24.6 \\
\hline 01073600 & Dudley Brook near Exeter, New Hampshire & 25,982 & .012 & 5.3 & .04 & 35.0 & 12.4 \\
\hline
\end{tabular}


For additional information call or write to:

Director, U.S. Geological Survey

Maine Water Science Center

196 Whitten Road, Augusta, Maine 04330

(207) 622-8201

http://me.water.usgs.gov 
